\title{
PEMBUATAN APLIKASI DATABASE SELEKSI PENERIMAAN KARYAWAN PADA PERUM PERUMNAS DENGAN MENGGUNAKAN MICROSOFT VISUAL BASIC 6.0
}

\author{
Achmad Sumbaryadi \\ AMIK BSI Jakarta \\ asumbaryadi@yahoo.com
}

\begin{abstract}
Data is a set of raw materials that have not been processed, so do not have a meaning and can not be used by users. So to do the data processing that is required quickly and accurately called the media system. PERUMNAS program has the reception of each new employee a certain period, the number of data of the applicants and the entry requirements required a system that can store and process data and print reports if needed at any time by the head.

By looking at the specifications needs create the Database System Application Using PERUMNAS With Microsoft Visual Basic 6.0. that can process the input data, process data, and print the results (reports).

Keywords $\quad$ : Database, aplication
\end{abstract}

\section{PENDAHULUAN}

1. Latar Belakang Masalah

Perusahaan Umum Pembangunan Perumahan Nasional (PERUM PERUMNAS) adalah sebuah Badan Usaha Milik Negara yang bergerak dalam bidang perumahan.

Setiap periode tertentu, PERUMNAS akan menerima karyawan baru sebagai karyawan berdasarkan pendidikan, status dan pengalaman yang dimiliki oleh calon karyawan (pelamar). Dengan banyaknya data pelamar yang masuk melalui pos dan e-mail, maka diperlukan waktu dan tenaga kerja yang cukup banyak dalam proses penyelesaian seleksi pelamar.

Sedangkan pada pengolahan data pelamar, PERUMNAS masih menggunakan proses manual. Ini terlihat dari proses pengumpulan seluruh berkas pelamar, yang selanjutnya dilakukan seleksi kemudian hasilnya di input dengan menggunakan MS Office Word dan Excel tetapi data tersebut tidak disimpan di dalam satu database. Hal ini yang menyebabkan tidak efisien, karena data-data pelamar bisa saja hilang dan sulit dilakukan pencarian apabila dibutuhkan sewaktu-waktu.

Penulis mencoba memberikan solusi terhadap masalah tersebut, dengan membuat aplikasi. Maka dengan adanya aplikasi database pengolahan data seperti, Input data, pencarian data, dan pembuatan laporan dapat lebih mudah. Software yang digunakan oleh penulis dalam pembuatan Aplikasi Database ini adalah phpMyAdmin-2.10.2 sebagai database dan
Microsoft Visual Basic 6.0. yang merupakan salah satu program pengolahan Database berbasis $M S$ Windows yang mempunyai kemampuan mengolah database.

\section{Batasan Masalah}

Penulis membatasi masalah pada pembuatan database dengan menggunakan phpMyAdmin2.10.2. Kemudian perancangan aplikasi menggunakan Microsoft Visual Basic 6.0 yang meliputi proses penyeleksian, pengolahan data, pembuatan laporan, serta perancangan proses dari sistem dan pembuatan laporan dengan Diagram Alir Data atau Data Flow Diagram (DFD).

\section{Tujuan Penelitian}

Tujuan dari penulisan laporan kerja praktek ini adalah Melakukan pembuatan aplikasi seleksi penerimaan karyawan pada PERUM PERUMNAS, serta penyimpanan seluruh data pelamar pada satu database untuk efisiensi waktu maupun tenaga kerja yang dibutuhkan pada proses input data maupun pengolahan data. Memudahkan pencarian data serta pembuatan laporan.

\section{KAJIAN TEORI}

1. MICROSOFT VISUAL BASIC 6.0

Microsoft Visual Basic 6.0 merupakan bahasa pemrograman yang bekerja dalam ruang lingkup $M S$-Windows. Secara umum, kemampuan VB 6.0 yaitu menyediakan komponen-komponen yang memungkinkan membuat sebuah program aplikasi yang sesuai dengan tampilan dan cara kerja Windows. MS-VB 6.0 hampir dapat memanfaatkan 
seluruh kemudahan dan kecanggihan yang dimiliki oleh Sistem Operasi Windows.

\section{BASIS DATA (DATABASE)}

Basis Data adalah sekumpulan data atau informasi yang teratur berdasarkan kriteria tertentu yang saling berhubungan. Basis Data tidak hanya berisi data, tetapi juga berisi rencana atau model data. Basis Data dapat menjadi sumber utama yang digunakan secara bersama-sama oleh berbagai pemakai dalam sebuah perusahaan sesuai dengan kebutuhan. Basis data dapat menyimpan dokumen yang berisi data dalam bentuk file teks, file spread sheet, dan lain-lain. Yang sangat ditonjolkan dalam basis data adalah pemilahan, pengelompokkan atau pengorganisasian data yang selanjutnya akan disimpan sesuai fungsi atau jenisnya. Pemilahan, pengelompokkan atau pengorganisasian ini dapat berbentuk sejumlah file atau tabel terpisah, dalam bentuk pendefinisian kolom-kolom atau field-field data dalam setiap file atau tabel.

\section{A. TABEL}

Sebuah tabel atau entity dalam model relasional digunakan untuk mendukung antar muka komunikasi antara pemakai dengan komputer.

\begin{tabular}{|c|c|c|c|c|c|c|c|c|}
\hline & Field & Type & Collation & Attributes & Null & Default & Extra & Action \\
\hline & NIKK & $\operatorname{int}(5)$ & & & No & & auto_increment & 䨘 $>$ X圆圆圆 \\
\hline$\square$ & nama_Lengkap & varchar (50) & utio_general_ci & & No & & & 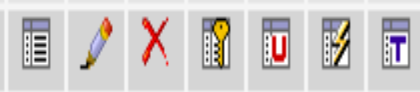 \\
\hline & SKOR & $\operatorname{int}(5)$ & & & No & & & 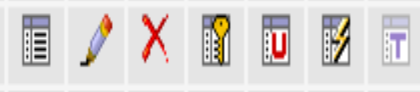 \\
\hline & keterangan & varchar(20) & utif__general_ci & & No & & & 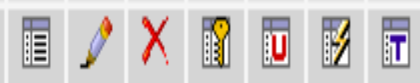 \\
\hline
\end{tabular}

Gambar 2.1 Contoh tabel pada phpMyAdmin-2.10.2

3. phpMyAdmin-2.10.2

phpMyAdmin dikembangkan menggunakan PHP dan berinterface web, sehingga selain harus terhubung dengan server, kita harus mempunyai web browser. Pada browser, ketikkan http://localhost/phpmyadmin atau nama servernya untuk mengakses phpMyAdmin kita.

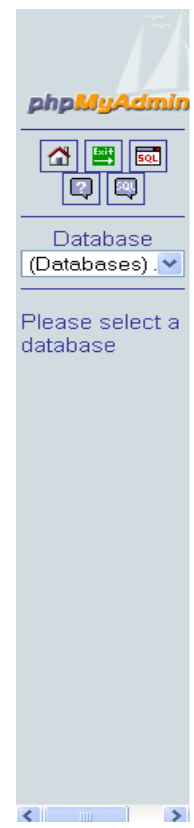

\section{localhost}

跑 Server version: 5.0.45-community-nt-log

- Protocol version: 10

捣 Server: localhost via TCP/P

- User: root@localhost

40 MySQL charset: UTF-8 Unicode (utf8)

迎 MySQL connection collation: utf8_unicode_c (7)

create new database$$
\text { Create }
$$

Show MySQL runtime information

Show MySQL system variables 0

解 Processes

堵 Character Sets and Collations

Storage Engines

I) Reload privileges (3)

5 Privileges

窞 Databases

臽 Export

唃 Import

팔 Log out (i)

\section{phpMyAdmin - 2.10.2}

- MySQL client version: 5.0 .37

- Used PHP extensions: mysq

Canguage (i) : English

\& Theme / Style: Original v

- Font size: $100 \%$ v

phpMyAdmin documentation

phpMyAdmin wiki

쇼 Official phpMyAdmin Homepage

- [ChangeLog] [Subversion] [Lists]

Gambar 2.2 Tampilan Awal pada phpMyAdmin-2.10.2 


\section{METODOLOGI}

1. Tempat dan Waktu

Tempat yang digunakan untuk mengerjakan pembuatan aplikasi ini adalah di PERUMNAS, dengan waktu yang dibutuhkan adalah 1 Bulan 3 Minggu. Maka sample dan data langsung dapat diminta dan diolah di PERUMNAS.

\section{Metodologi Penulisan}

Metodologi yang dilakukan penulis pada penelitian ini adalah :

1) Pengumpulan Data

Dalam proses pengumpulan data ini meliputi kegiatan wawancara dan observasi, Studi Literatur, dan diskusi.

2) Analisa Sistem

Penulis membuat aplikasi ini menggunakan pemrograman Microsoft Visual Basic 6.0, yang merupakan bahasa pemrograman tingkat tinggi yang berbasis windows. Apabila seluruh data pelamar sudah diinput, kemudian dilakukan proses penyeleksian berdasarkan persyaratan, selanjutnya proses pengolahan pelamar yang berhak mengikuti test, tahap terakhir adalah penginputan kembali hasil test. Maka dihasilkanlah data pelamar yang LULUS persyaratan dan test seleksi, dan data pelamar yang DITERIMA sebagai karyawan di PERUMNAS.

3) Perancangan Sistem

Pada tahap ini adalah proses pembuatan :

1) Data Flow Diagram (DFD) perbaikan dari sistem yang sedang berjalan.

2) Entity Relationship Diagram (ERD) untuk merencanakan basis data dan hubungan.

3) Normalisasi dan Kamus Data.

4) Penelusuran Akses (Access Path).

5) Bagan terstruktur yang tersusun dari beberapa spesifikasi modul.

4) Perancangan Aplikasi

Pada tahap perancangan aplikasi ini, diawali dengan installasi dan pembuatan phpMyAdmin-2.10.2 sebagai database, Microsoft Visual Basic 6.0 sebagai form interface, serta mysql-connector-odbc-3.51.12win32 sebagai connector (penghubung) antara database dengan aplikasi VB.

5) Testing Sistem

Tahap testing (pengetesan) sistem dilakukan untuk memeriksa koordinasi antar komponen sistem yang akan diimplementasikan. Agar dapat dipastikan bahwa seluruh elemen sistem telah berfungsi sesuai dengan yang diharapkan.
6) Implementasi Sistem

Setelah sistem dianalisa dan didesain secara terperinci, tahap akhir yaitu pengimplementasian agar sistem dapat beroperasi sesuai harapan dan tahapan tahapannya.

\section{HASIL DAN PEMBAHASAN}

4.1. Perangkat yang diperlukan dalam Pembuatan Aplikasi Database Seleksi Penerimaan Karyawan PERUMNAS

1. Hardware
a. Monitor min 14"
b. Processor pentium IV
c. Hardisk $80 \mathrm{~Gb}$
d. DDRAM $256 \mathrm{Mb}$
e. $V G A 64 \mathrm{Mb}$
f. Keyboard dan Mouse
g. Printer

2. Software

Sistem Operasi yang digunakan dalam pembuatan aplikasi ini yaitu, Windows XP Profesional yang telah terinstall software $M S$ Visual Basic 6.0, phpMyAdmin-2.10.2 dan mysql-connector-odbc-3.51.12-win32.

\subsection{Perancangan Database}

Dalam pembuatan sebuah Aplikasi Database dibutuhkan sebuah perencanaan yang dapat melayani kebutuhan aplikasi pengolahan database tersebut.

Untuk mendesain suatu database penulis akan menerangkan beberapa pembahasan perancangan database seperti berikut ini :

1. Data Flow Diagram (DFD)

2. Spesifikasi Proses

3. Entity Relationship Diagram (ERD)

4. Transformasi ERD ke LRS

5. Normalisasi

6. Data Dictionary (Kamus Data)

7. Access Path

8. Pseudocode (Pengkodean)

\section{A. Data Flow Diagram (DFD)}

Data Flow Diagram (DFD) adalah model dari sebuah sistem yang digunakan untuk menggambarkan pembagian system kedalam modul yang lebih kecil. Keuntungannya adalah untuk mempermudah User atau pemakai yang kurang menguasai bidang komputer untuk memahami sistem yang akan dikerjakan. Untuk membuat DFD diperlukan langkah-langkah dari pembuatan diagram konteks, diagram nol (zero) sampai dengan pembuatan diagram detail. 


\section{1) Diagram Konteks}

Pada Diagram Konteks merupakan penggambaran alur dari sistem secara umum. Pada
PERUMNAS Diagram Konteks dari Aplikasi Database Seleksi Penerimaan Karyawan, yaitu : (Gambar 4.2)

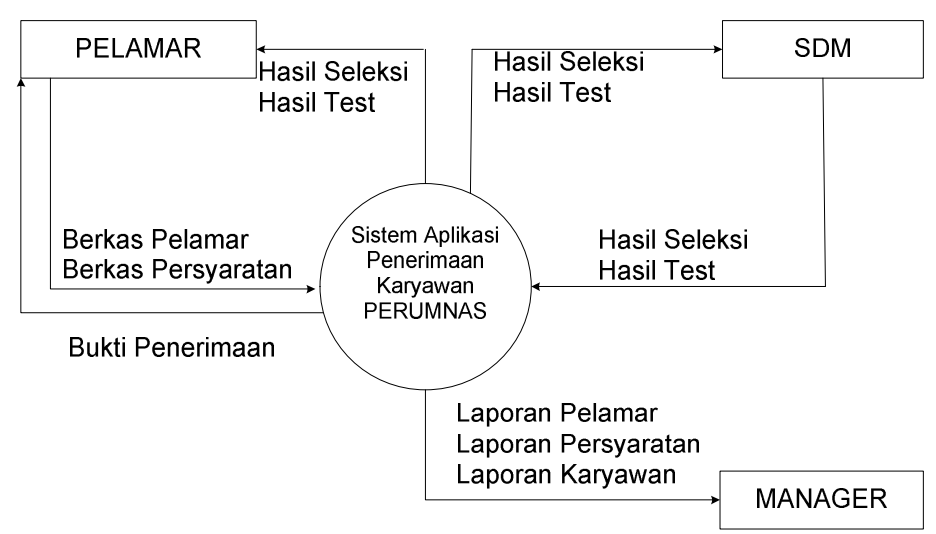

Gambar 4.2 Diagram Konteks

2) Diagram Nol (Zero)

Pada Diagram Nol, merupakan penggam-baran sistem secara keseluruhan. Diagram Nol dari
Aplikasi Seleksi Penerimaan Karyawan, yaitu : (Gambar 4.3)

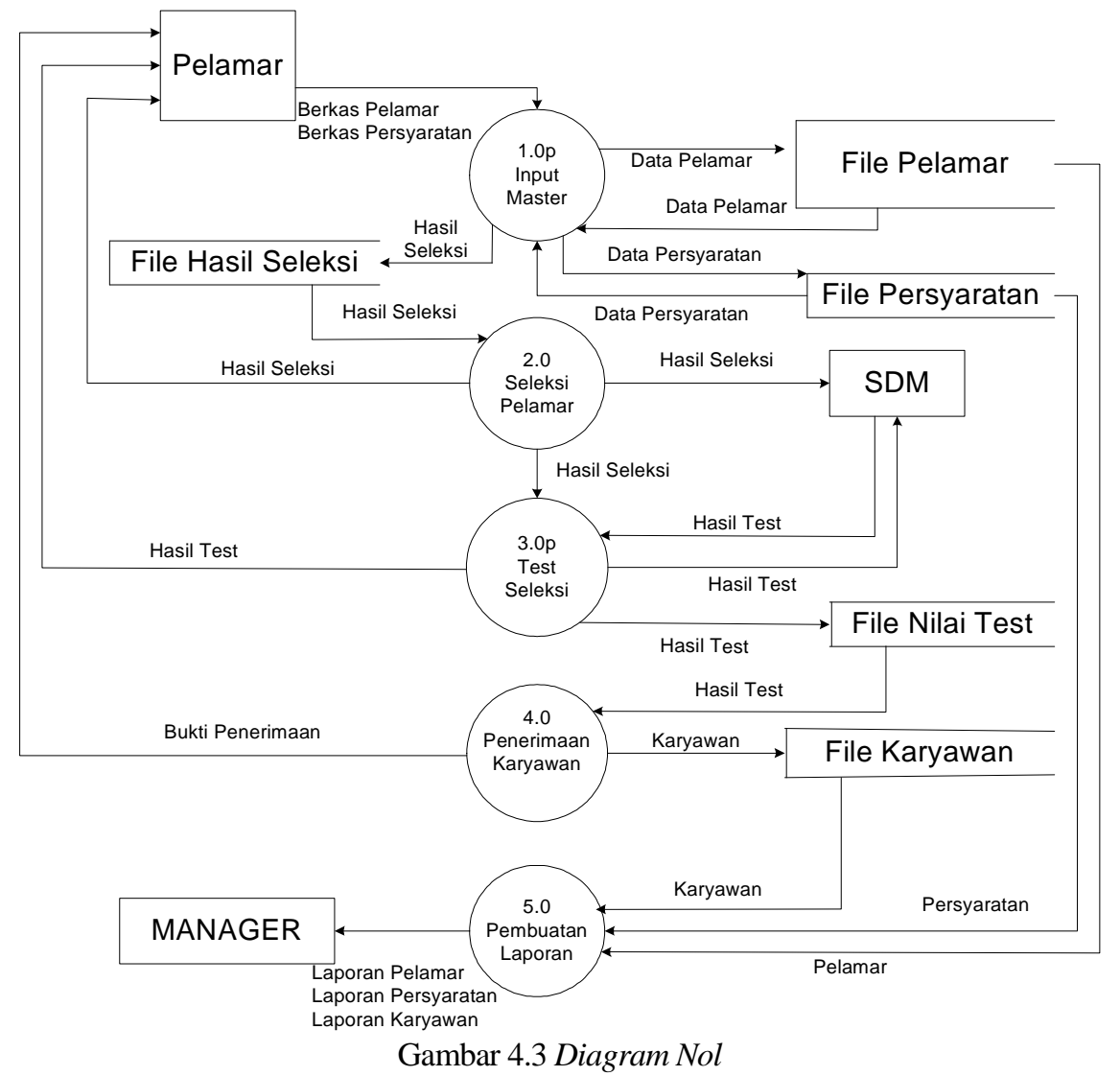




\section{3) Diagram Detail}

Diagram ini dibuat untuk menggambarkan arus data secara lebih detail lagi dari tahapan proses pada diagram nol. Berikut ini merupakan Diagram Detail pada proses 2.0 pada Diagram Nol : (Gambar 3.4)

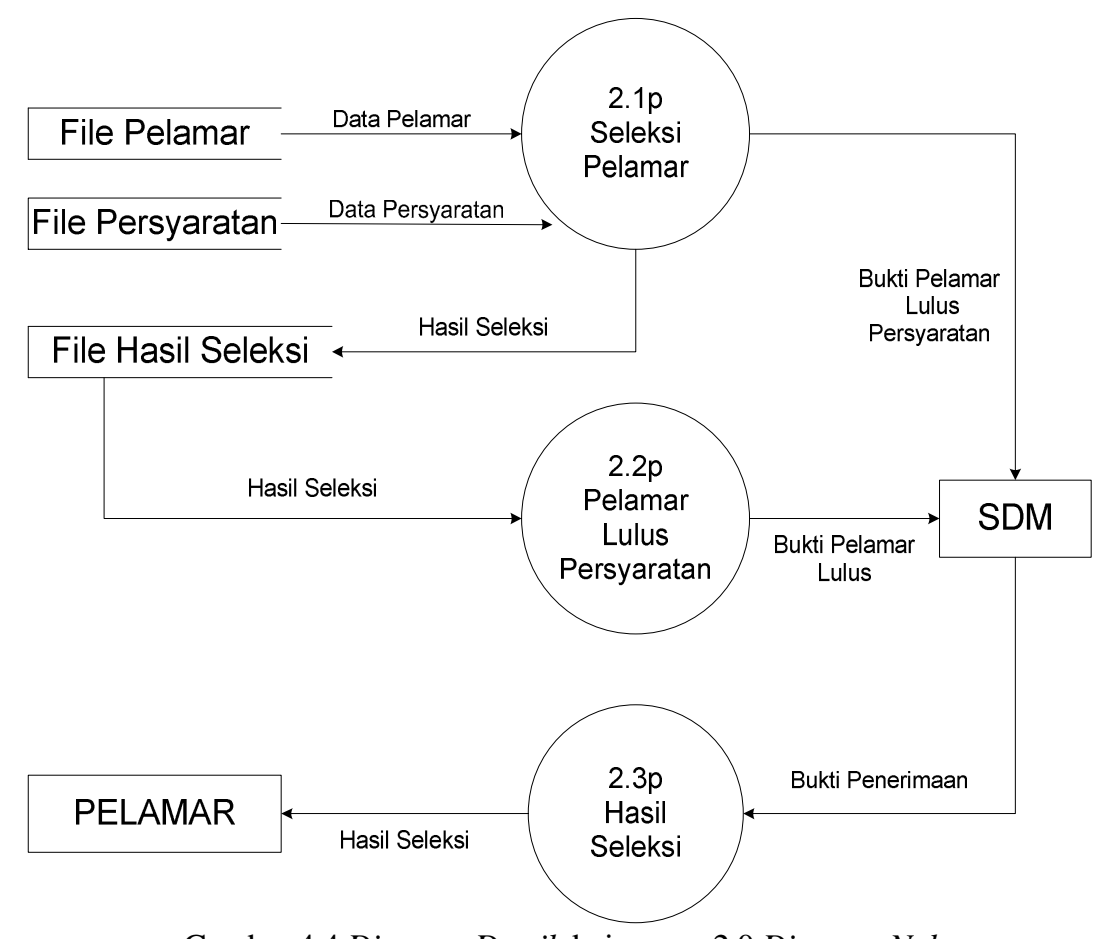

Gambar 4.4 Diagram Detail dari proses 2.0 Diagram Nol

Kemudian Diagram Detail 4.0 dari Diagram Nol, yaitu : (Gambar 4.5)

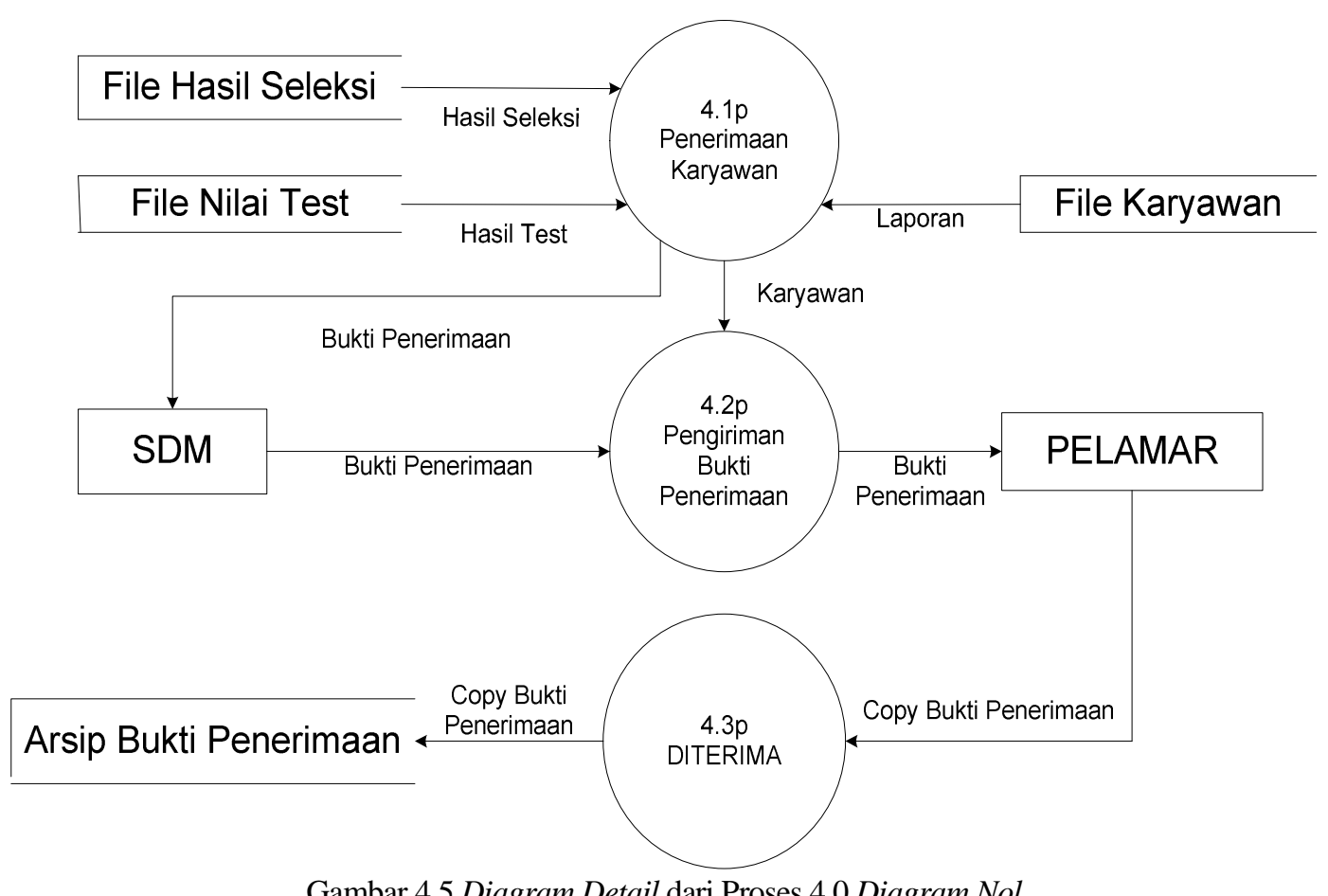

Gambar 4.5 Diagram Detail dari Proses 4.0 Diagram Nol 
Kemudian Diagram Detail 5.0 dari Diagram Nol, yaitu : (Gambar 4.6)

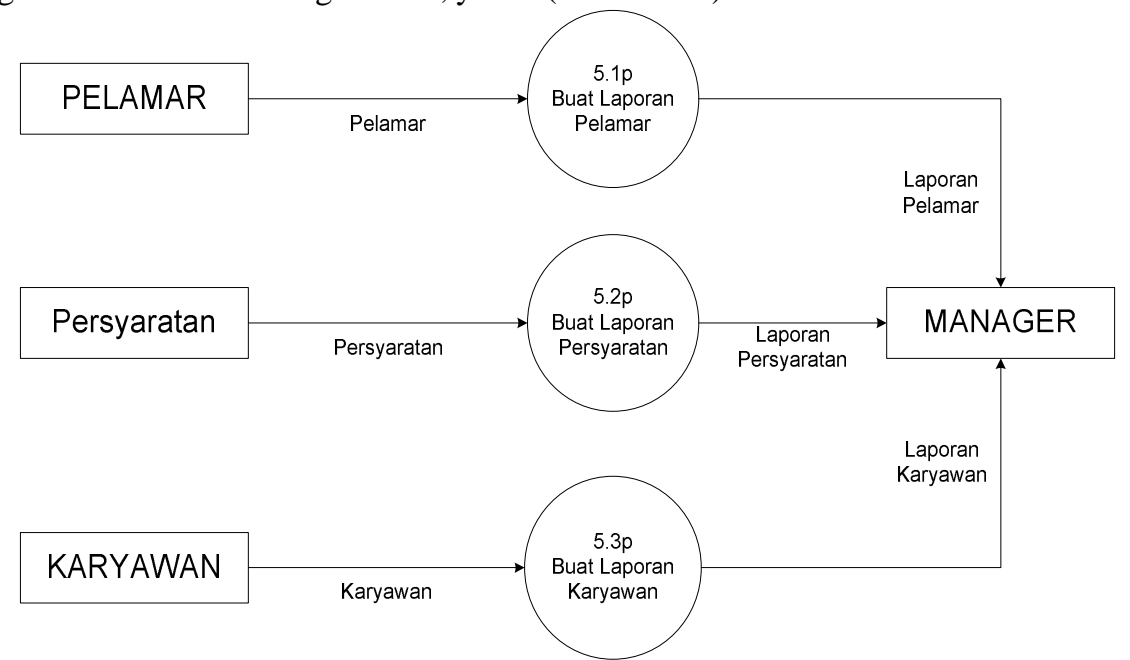

Gambar 4.6 Diagram Detail Proses 5.0 Diagram Nol

B. Spesifikasi Proses

1) Nomor : $1.0 \mathrm{p}$

Nama Proses : Input Master

Masukan : Berkas Pelamar, Persyara$\tan$

Keluaran : Hasil Seleksi

Uraian Proses : Menerima berkas pelamar dan berkas persyaratan, input data pelamar dan data persyaratan

2) Nomor $: 2.1 \mathrm{p}$

Nama Proses : Seleksi Pelamar

Masukan : Data Pelamar dan Data

Persyaratan

Keluaran : Hasil Seleksi, Bukti Pelamar Lulus Persyaratan, Bukti Pelamar Lulus, Bukti Penerimaan

Uraian Proses : Hasil Seleksi pelamar di simpan ke dalam file hasil seleksi dan di hasilkan bukti pelamar lulus persyaratan

3) Nomor : $2.2 \mathrm{p}$

Nama Proses : Pelamar Lulus Persyaratan

Masukan

: Hasil Seleksi

Keluaran

: Bukti Pelamar yang Lulus persyaratan, bukti penerimaan

Uraian Proses :

- Baca Hasil Seleksi

- Pelamar yang lulus persyaratan

- Dibuat Bukti pelamar yang lulus

- Dibuat bukti penerimaan
4) Nomor : $2.3 \mathrm{p}$

Nama Proses : Hasil Seleksi

Masukan : Bukti Penerimaan

Keluaran : Hasil Seleksi

Uraian Proses:

- SDM membuat bukti penerimaan pelamar

- Hasil Seleksi diterima pelamar

5) Nomor : $4.1 \mathrm{p}$

Nama Proses : Penerimaan Karyawan

Masukan : Hasil Seleksi, Hasil Test, Laporan

Keluaran : Bukti Penerimaan, Karyawan

Uraian Proses :

- Baca hasil seleksi dan hasil test

- SDM membuat bukti penerimaan karyawan

6) Nomor : $: 4.2 \mathrm{p}$

Nama Proses : Pengiriman Bukti Penerimaan

Masukan : Bukti Penerimaan

Keluaran : Bukti Penerimaan

Uraian Proses:

- SDM mengirimkan Bukti Penerimaan kepada pelamar

- Pelamar menerima bukti penerimaan Karyawan

7) Nomor : $4.3 p$

Nama Proses : DITERIMA

Masukan : Copy Bukti Penerimaan

Keluaran : Copy bukti Penerimaan

Uraian Proses:

- Copy bukti penerimaan disimpan ke dalam arsip bukti penerimaan 


\section{Entity Relationship Diagram (ERD)}

Tujuan Pembuatan ERD adalah untuk memperjelas hubungan antar entitas. Pada sistem Seleksi Penerimaan Karyawan, dapat dilihat bentuk ERD sebagai berikut : (Gambar 4.7)
Pada Gambar 4.7 dapat dilihat relasi - relasi atau hubungan yang terbentuk dari masing masing tabel pada database pelamar. Kemudian dari ERD tersebut dapat dilihat pula Cardinality dan Primary Key pada masing - masing tabel, sehingga dapat memudahkan relasi terbentuknya tabel - tabel yang akan dihasilkan nantinya.

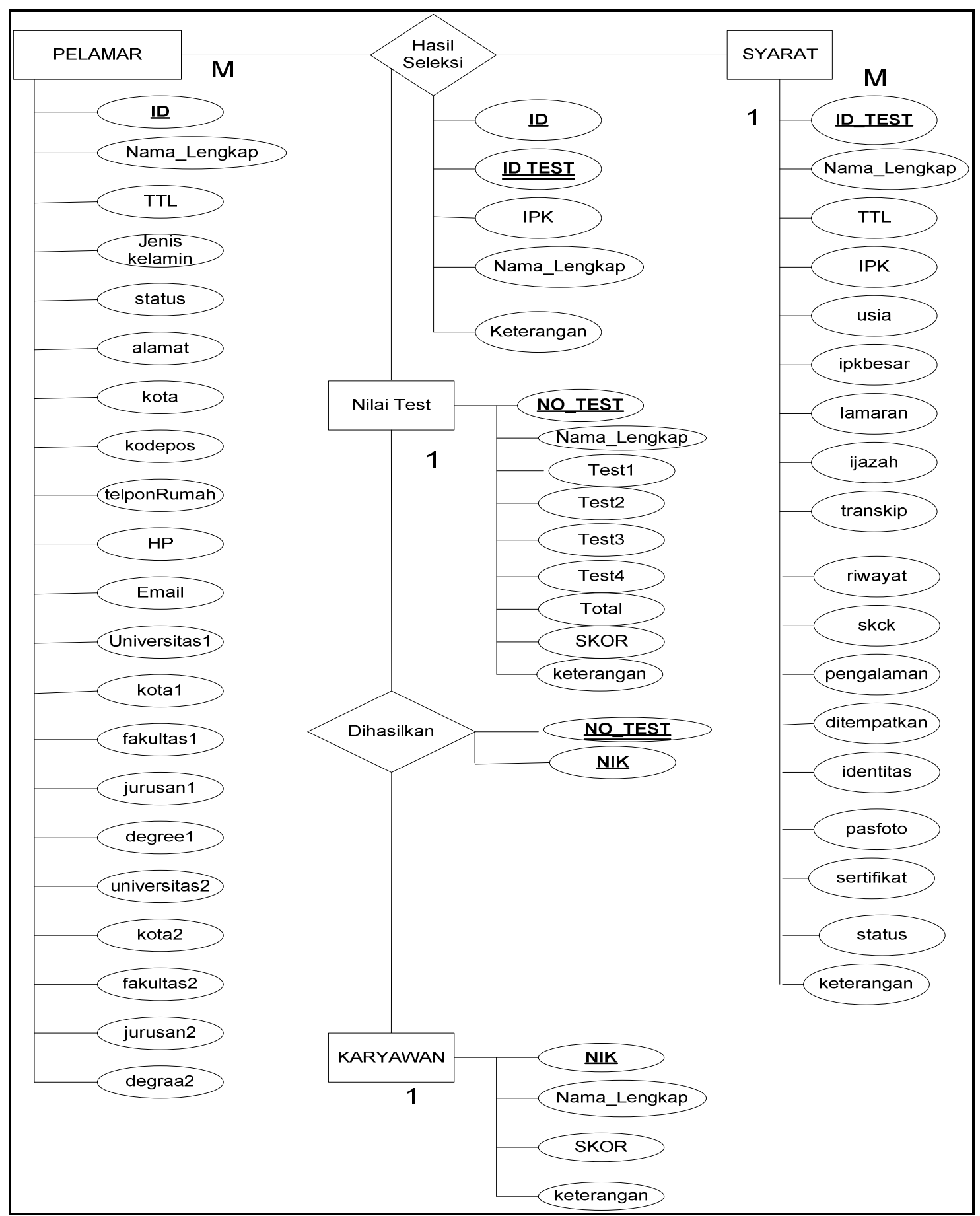

Gambar 4.7 Entity Relationship Diagram (ERD) 


\section{Transformasi ERD ke LRS}

Dalam kaitannya dengan transformasi dari diagram ERD ke LRS. Perubahan yang terjadi mengakui aturan-aturan, yaitu Sebuah relasi kadang disatukan dengan sebuah entitas, kadang dipisahkan dalam sebuah kotak tersendiri. Dari ERD Sistem Seleksi Penerimaan Karyawan PERUMNAS, maka dapat digambarkan proses transformasi ERD ke LRS, sebagai berikut :

(Gambar 4.8)

Relasi merupakan pernyataan data secara grafis antara dua dimensi yang terjadi dari dua kolom dan baris. Pada setiap perpotongan antara kolom dan baris mempunyai nilai isi. Relasi merupakan bentuk visual dari sebuah file, setiap baris pada setiap relasi mewakili sebuah field. Transformasi LRS ke dalam relasi dilakukan dengan cara :

1. Nama Logical Record sebuah kolom di dalam relasi.

2. Setiap atribut menjadi sebuah kolom di dalam relasi.

Maka hasil transformasi dari ERD ke LRS adalah sebagai berikut : (Gambar 4.9)

Pada Transformasi dari ERD ke LRS, dibuatlah pengelompokkan table - tabel berdasarkan Cardinality yang membentuk tabel tersebut. Pengelompokkan tersebut digambarkan dengan garis putus - putus seperti pada gambar 4.8.

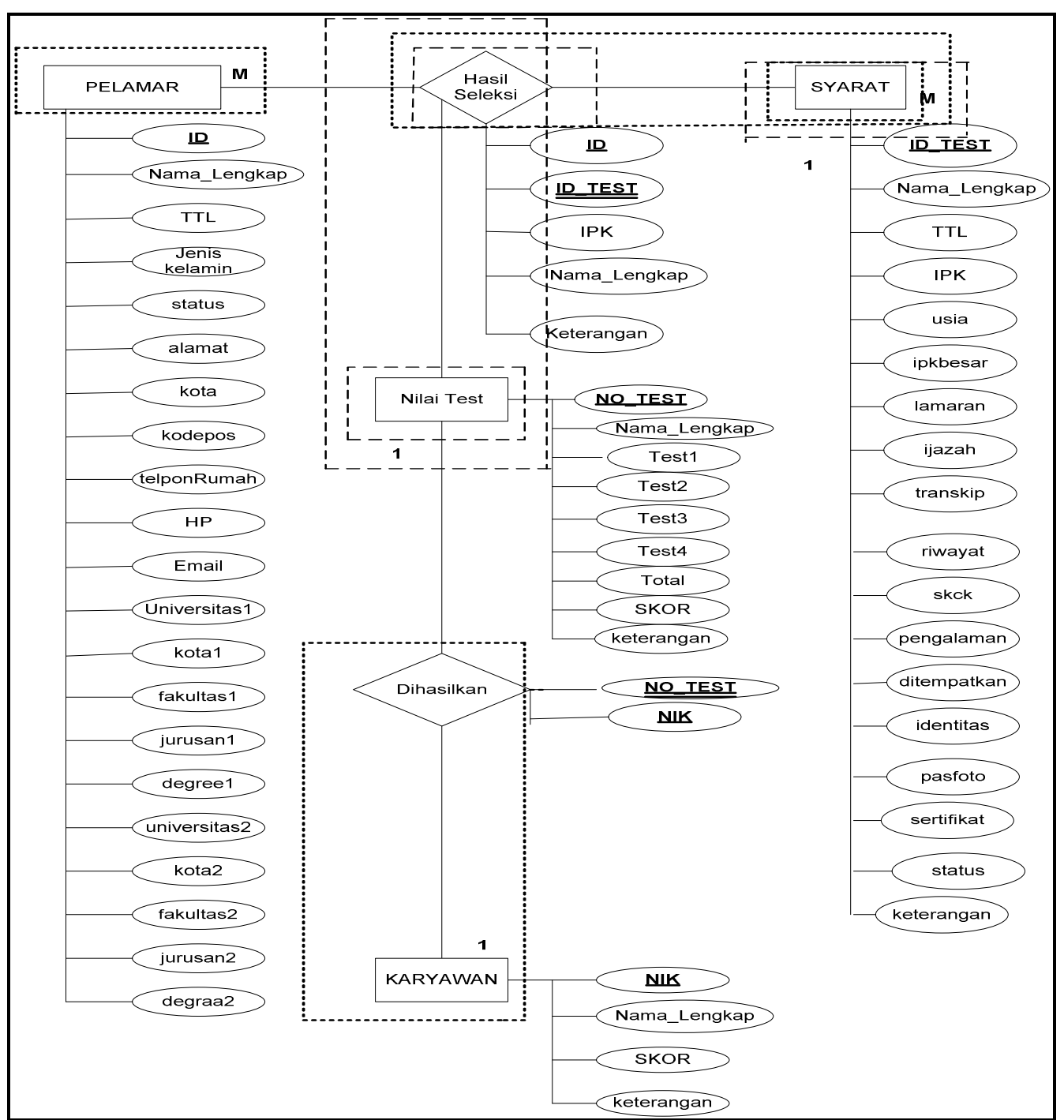

Gambar 4.8 Transformasi ERD ke LRS 


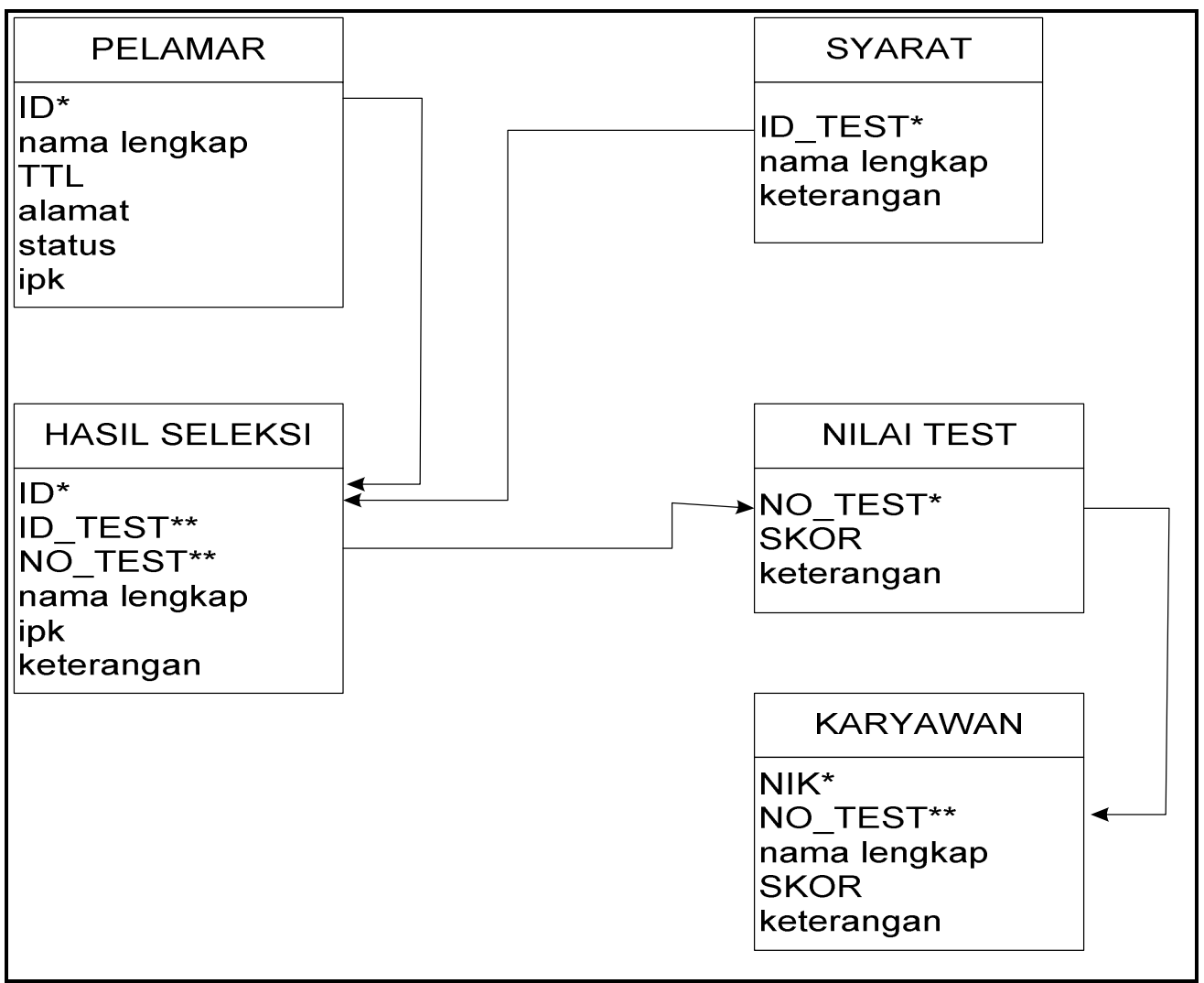

Gambar 4.9 Logical Record Structure

Maka dari proses transformasi dihasilkan 5 tabel yaitu tabel pelamar, syarat, hasil seleksi, nilai test dan tabel karyawan sesuai dengan gambar LRS di atas. Dari gambar diatas dapat dilihat relasi yang terbentuk pada masing masing tabel, seperti tabel hasil seleksi dihasilkan dari tabel pelamar dan tabel syarat.

\section{E. Normalisasi}

Normalisasi adalah bentuk relasi yang mendukung kerangkapan data yang minimal. Tujuan dari normalisasi adalah untuk menandakan anomaly pada tupple operation, terjaminnya struktur data yang konsisten serta memaksimalkan kestabilan data.

Tabel 3.1 Bentuk UNNORMAL

\begin{tabular}{|c|c|c|c|c|c|}
\hline ID & ID_TEST & NO_TEST & NIK & Nama lengkap & keterangan \\
\hline 1 & 01201 & 012 & 201 & Hari Cakra & LULUS \\
\hline 2 & 02342 & 312 & 349 & Gunawan Arif & TIDAK LULUS \\
\hline 1 & 01201 & 012 & 201 & Hari Cakra & LULUS \\
\hline 4 & 04344 & 235 & 761 & Ananda & TIDAK LULUS \\
\hline
\end{tabular}

Dari tabel UnNormal diatas, dapat dilihat adanya pengulangan record - record. Maka hal ini perlu dilakukan lagi tahapan $1 \mathrm{NF}, 2 \mathrm{NF}$ untuk menghilangkan data yang bersifat atomic, agar tidak ada lagi pengulangan. Bentuk UnNormal digambarkan seperti berikut ini : 


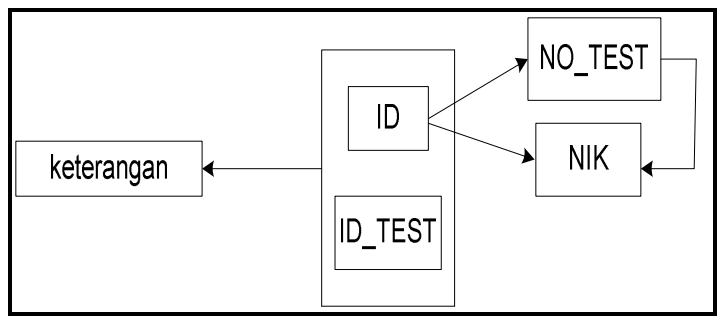

Bentuk UnNormal di atas menggambarkan bahwa pada NO_TEST dan NIK bergantung pada ID, sedangkan NIK bergantung pada NO_TEST

dan inilah yang disebut dengan ketergantungan fungsional. Dari bentuk UnNormal maka tabel yang dihasilkan, yaitu :

Tabel 3.2 Bentuk 1NF

Tabel Hasil Seleksi

\begin{tabular}{|c|c|c|c|}
\hline$\underline{\text { ID }}$ & $\underline{\text { ID_TEST }}$ & Nama lengkap & keterangan \\
\hline 1 & 01201 & Hari Cakra & LULUS \\
\hline 2 & 02342 & Gunawan Arif & TIDAK LULUS \\
\hline
\end{tabular}

Tabel Nilai Test

\begin{tabular}{|c|c|c|c|c|}
\hline ID TEST & NO TEST & NIK & Nama lengkap & keterangan \\
\hline 01201 & 012 & 201 & Hari Cakra & DITERIMA \\
\hline 02342 & 312 & 349 & Gunawan Arif & DITERIMA \\
\hline
\end{tabular}

Dari tabel bentuk 1NF diatas, tabel - tabel yang terbentuk yaitu tabel hasil seleksi dan tabel nilai test. Tetapi tabel ini masih dapat dipecah lagi menjadi satu tabel lagi, maka proses normalisasi akan terus berlanjut hingga ketergantungan sudah tidak ada lagi. Bentuk 1NF digambarkan sebagai berikut :

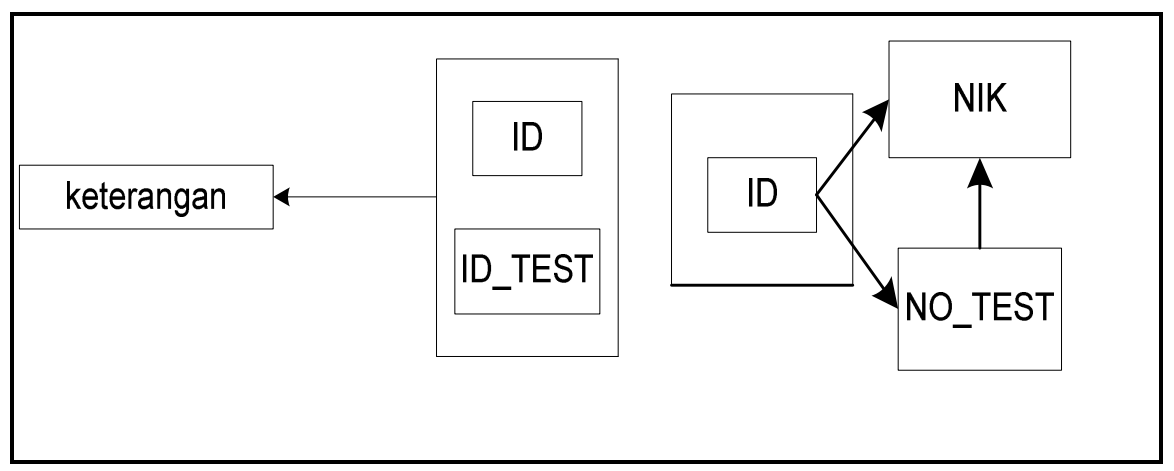

Bentuk 1NF diatas menunjukkan adanya ketergantungan antara ID dengan NIK dan NO_TEST. Tetapi pada bentuk 1NF tabel pelamar dengan primary key ID dan tabel syarat dengan primary key ID_TEST telah memenuhi normalisasi. Dari bentuk 2NF, maka tabel yang dihasilkan sebagai berikut : 
Tabel 3.3 Bentuk 2NF

Tabel Hasil Seleksi

\begin{tabular}{|c|c|c|c|}
\hline$\underline{\text { ID }}$ & $\underline{\underline{\text { ID TEST }}}$ & Nama lengkap & keterangan \\
\hline 1 & 01201 & Hari Cakra & LULUS \\
\hline 2 & 02342 & Gunawan Arif & TIDAK LULUS \\
\hline
\end{tabular}

Tabel Nilai Test

\begin{tabular}{|c|c|c|}
\hline NO_TEST & Nama lengkap & keterangan \\
\hline 012 & Hari Cakra & DITERIMA \\
\hline 312 & Gunawan Arif & DITERIMA \\
\hline
\end{tabular}

Tabel Karyawan

\begin{tabular}{|c|c|c|}
\hline NIK & Nama lengkap & keterangan \\
\hline 201 & Hari Cakra & DITERIMA \\
\hline 349 & Gunawan Arif & DITERIMA \\
\hline
\end{tabular}

Pada normalisasi bentuk 2NF tabel yang dihasilkan bertambah yaitu tabel karyawan. Untuk bentuk $2 \mathrm{NF}$ dapat digambarkan sebagai berikut :

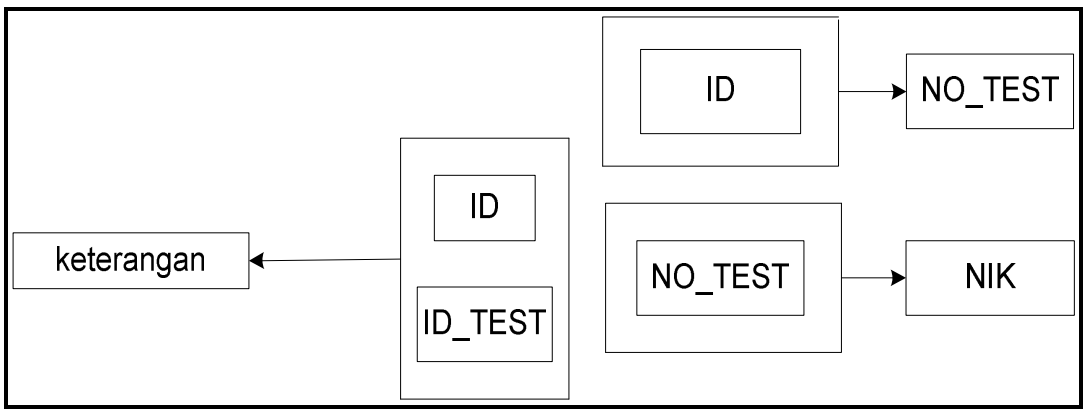

Gambar diatas menunjukkan bahwa semua tabel tidak ada lagi ketergantungan satu dengan yang lain.

\section{F. Data Dictionary (Kamus Data)}

Kamus data adalah basis data yang berisi struktur data dan basis data, termasuk di dalam katalog semua elemen data yang terdiri dari nama, struktur, dan informasi tentang penggunaan data.

1. Nama arus data : Data Hasil Seleksi
Alias
: Hasil Seleksi
Bentuk data
: Kertas
Arus data
: Pelamar - Proses 1.0,
Persyaratan - Proses 1.0
Penjelasan
: Data identitas diri pelamar
Periode
: Setiap ada berkas pelamar yang masuk
Volume
: 200/bulan
Struktur data
Header

Isi

Footer

$:$ ID + nama lengkap + TTL + Jenis Kelamin + Alamat + Status + ipk

: Tanda Tangan Ketua Tim + Tanda Tangan Petugas Seleksi Administrasi

2. Nama arus data : Data Karyawan

Alias : Karyawan

Bentuk data : Kertas

Arus data : Hasil Test - Proses 4.0

Penjelasan : Bukti Penerimaan

Periode : Setiap ada hasil test

Volume : 200/bulan

Struktur data : Header + Isi + Footer

Header : Nama Perusahaan +

Alamat Perusahaan

Isi
: NIK + nama lengkap + SKOR + keterangan 
Footer

\section{: Tanda Tangan Ketua Tim + Tanda Tangan Petugas Seleksi Administrasi}

\section{G. Access Path}

Berdasarkan analisa tinjauan program, penulis berpendapat bahwa untuk penelusuran akses program adalah sebagai berikut :

1. Input master

$$
(1.0 \mathrm{p})=\mathrm{A}
$$

2. Seleksi pelamar

$$
(2.1 \mathrm{p})=\mathrm{B}
$$

3. Pelamar lulus persyaratan

4. Hasil Seleksi

$$
(2.3 \mathrm{p})=\mathrm{D}
$$

5. Test Seleksi

$$
\text { (3.0p) = E }
$$

6. Penerimaan karyawan

$$
\text { (4.1p) }=\mathrm{F}
$$

7. Pengiriman

$$
(4.2 \mathrm{p})=\mathrm{G}
$$

8. DITERIMA

$$
(4.3 \mathrm{p})=\mathrm{H}
$$

9. Buat laporan karyawan

$$
(5.1 \mathrm{p})=\mathrm{I}
$$

10. Buat laporan persyaratan

11. buat laporan karyawan

$$
(5.3 \mathrm{p})=\mathrm{K}
$$
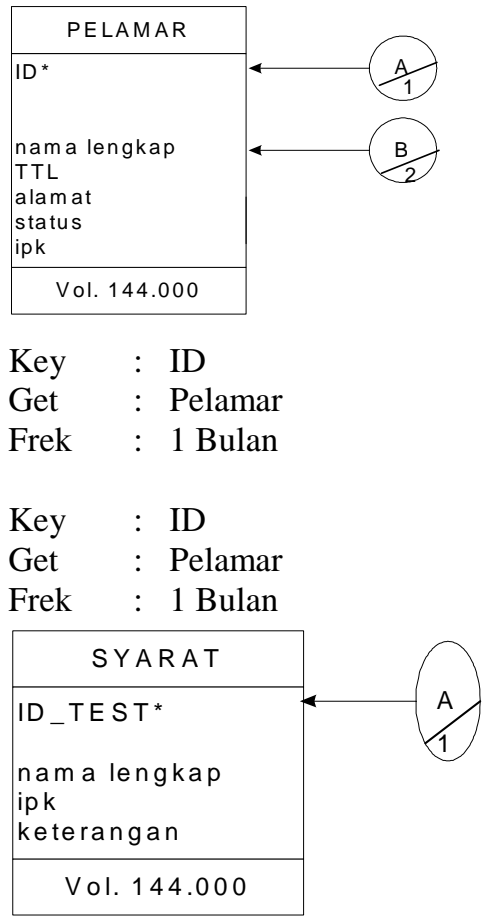

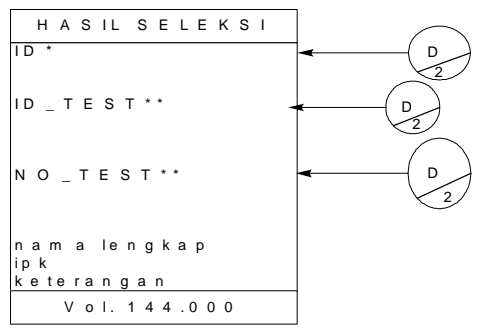

$\begin{array}{ll}\text { Key } & : \text { ID_TEST } \\ \text { Get } & : \text { Syarat } \\ \text { Frek } & : \text { 1 Bulan } \\ & \\ \text { Key } & : \text { ID } \\ \text { Get } & : \text { Pelamar } \\ \text { Frek } & : \text { 1 Bulan } \\ & \\ \text { Key } & : \text { NO_TEST } \\ \text { Get } & : \text { Nilai Test } \\ \text { Frek } & : \text { 1 Bulan } \\ & \\ \text { Key } & : \text { ID_TEST } \\ \text { Get } & : \text { Syarat } \\ \text { Frek } & : \text { 1 Bulan }\end{array}$

Gambar 4.10 Access Path Pelamar, Syarat, dan Hasil Seleksi

Key: NO_TEST

Get: Nilai Test

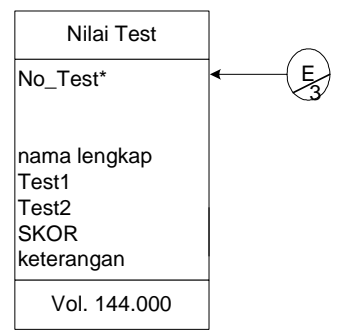

Gambar 4.11 Access Path Nilai Test

Key: NIK

Get: Karyawan

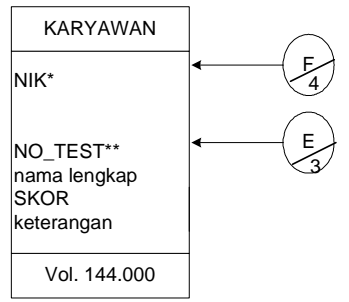

Frek: 1 Bulan

Key : NO_TEST 
Get : Nilai test

Frek: 1 Bulan

Gambar 4.12 Access Path Karyawan

Pada gambar Access Path di atas, menunjukkan field (Primary Key) yang diambil berdasarkan tabel dan kamus data yang dibutuhkan. Seperti dapat dilihat pada Access Path
Pelamar yang di ambil adalah data berdasarkan ID dan dengan frekuensi 1 bulan, dan begitu pula seterusnya.

\section{H. Structure Chart (Bagan Terstruktur)}

Berdasarkan analisa tinjauan program, penulis berpendapat bahwa untuk bagan terstruktur (structure chart) program adalah sebagai berikut

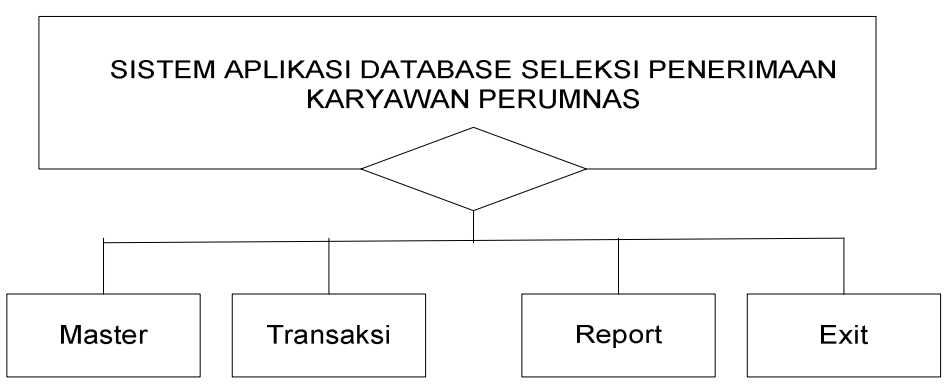

Gambar 4.13 Bagan Terstruktur Sistem Seleksi Penerimaan Karyawan PERUMNAS

Bagan terstruktur diatas menunjukkan menu utama yang ada pada aplikasi penerimaan kar- yawan ini. Dimana menu utama yaitu terdiri dari Master, Transaksi, Report, dan Exit.

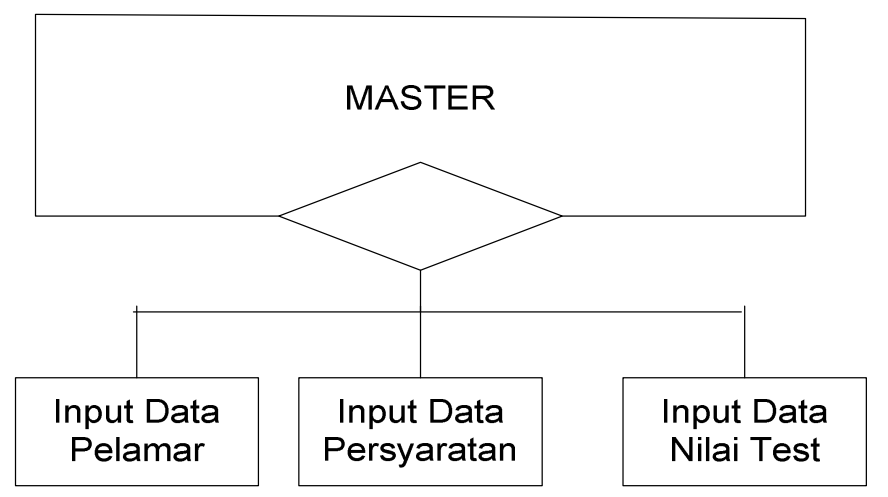

Gambar 4.14 Bagan Terstruktur Master

Sedangkan untuk menu Master memiliki menu - menu lagi yang terdiri dari Input data pelamar, input data persyaratan, dan input data nilai test.

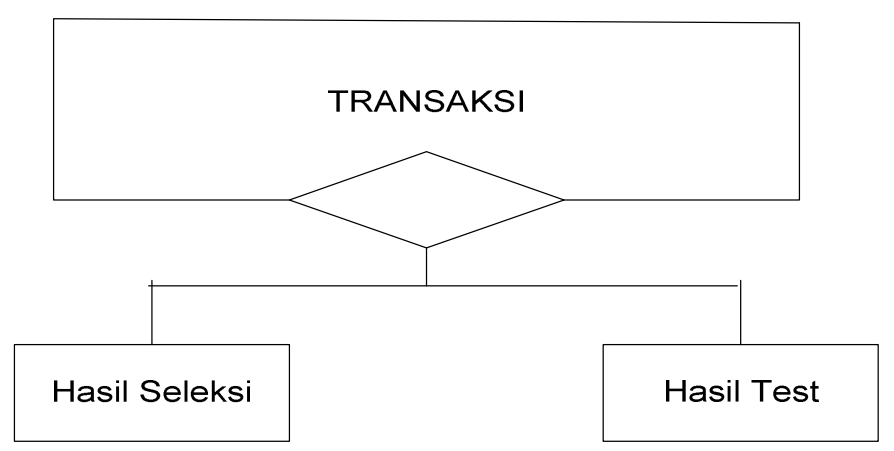

Gambar 4.15 Bagan Terstruktur Transaksi 
Kemudian pada menu Transaksi terdapat menu hasil seleksi dan hasil test, yang mana kedua pilihan menu ini merupakan hasil dari proses penyeleksian dari pelamar yang masuk.

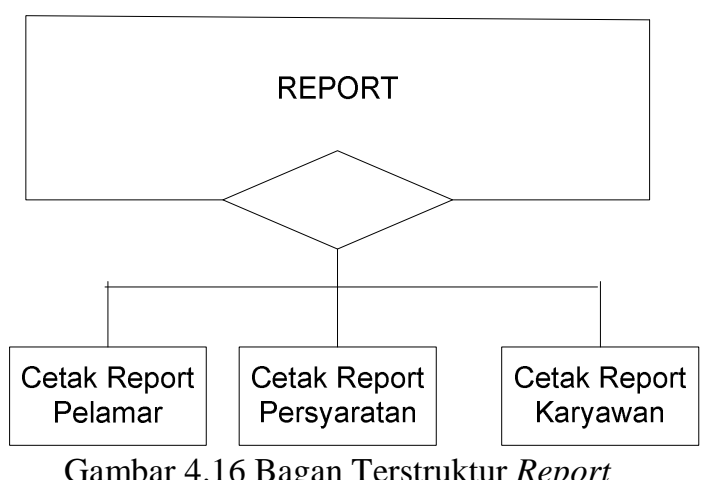

Sedangkan untuk gambar diatas menunjukkan menu Report yang juga terdiri lagi dari pilihan menu, yaitu cetak report pelamar, cetak report persyaratan, dan cetak report karyawan.
Dimana menu Report ini merupakan bentuk cetakan laporan yang nantinya akan diserahkan kepada Manager.

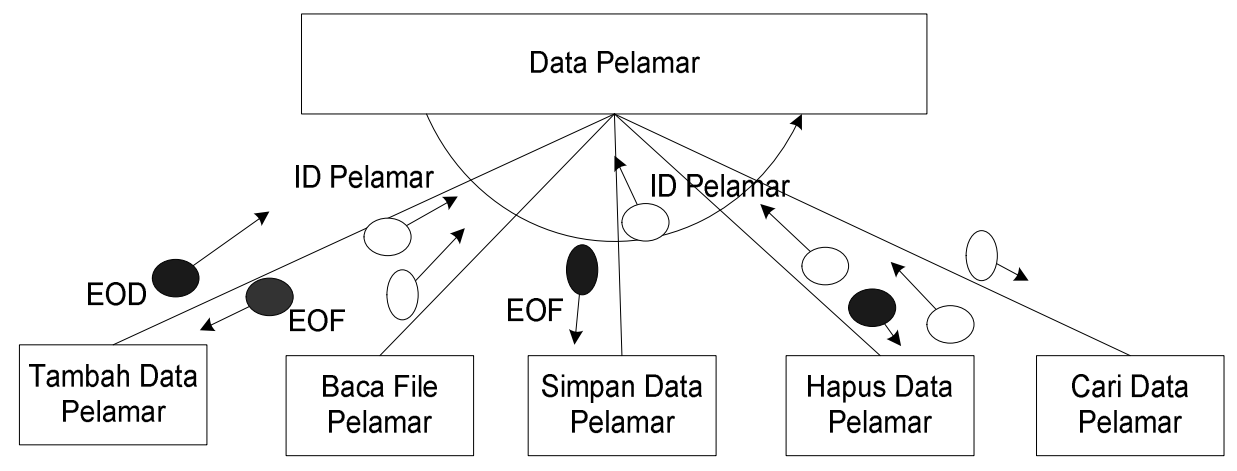

Gambar 4.17 Bagan Terstruktur Pelamar

Gambar bagan terstruktur pelamar diatas merupakan gambaran pada saat proses input data pelamar, proses yang berjalan yaitu tambah data pelamar, baca file pelamar, simpan data pelamar, hapus data pelamar, dan cari data pelamar.

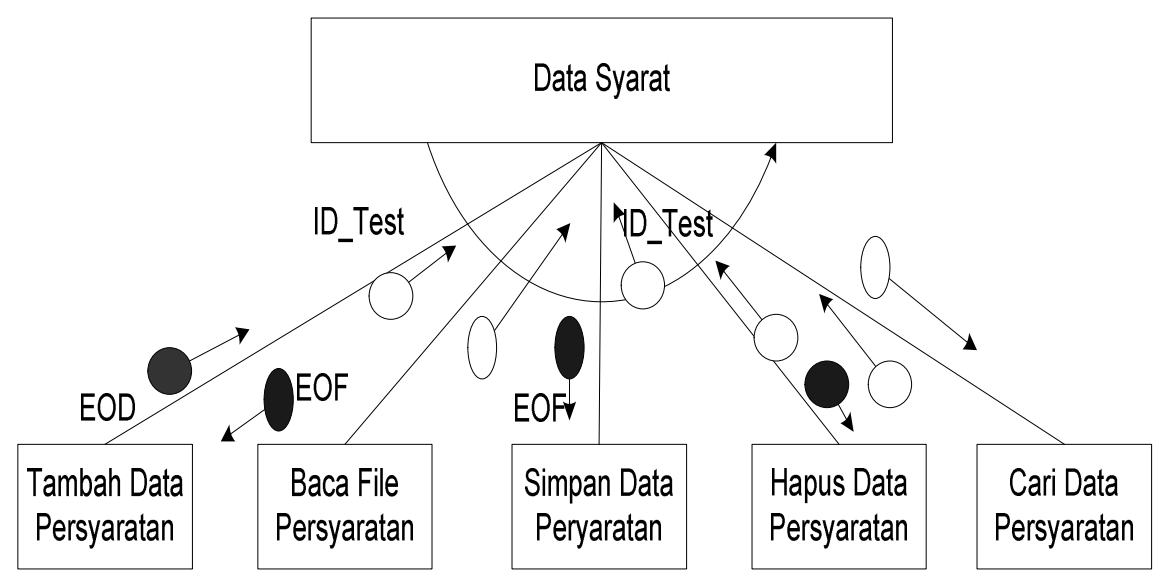

Gambar 4.18 Bagan Terstruktur Persyaratan 


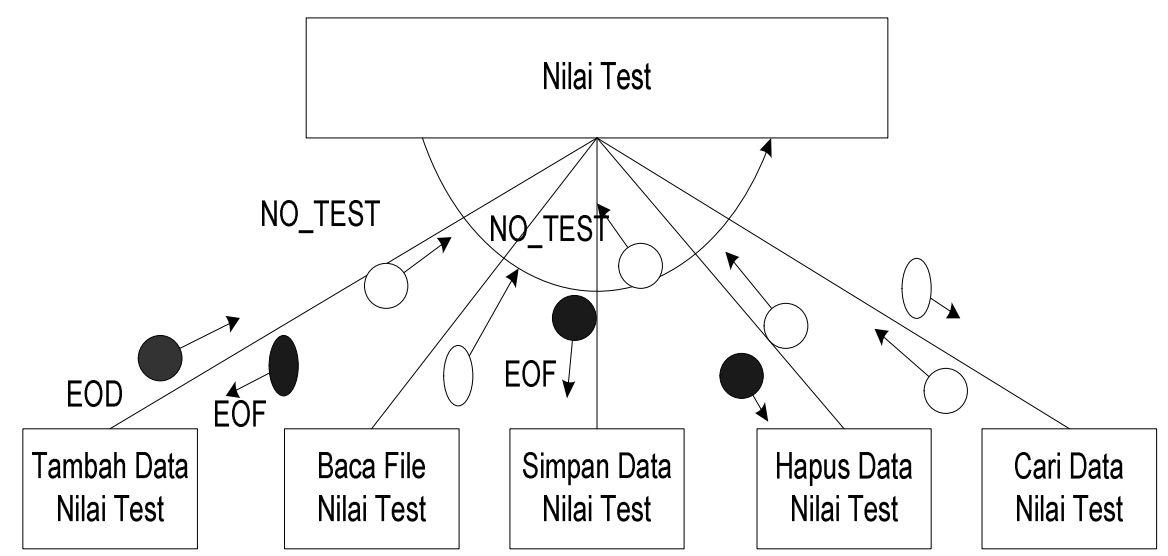

Gambar 4.19 Bagan Terstruktur Nilai Test
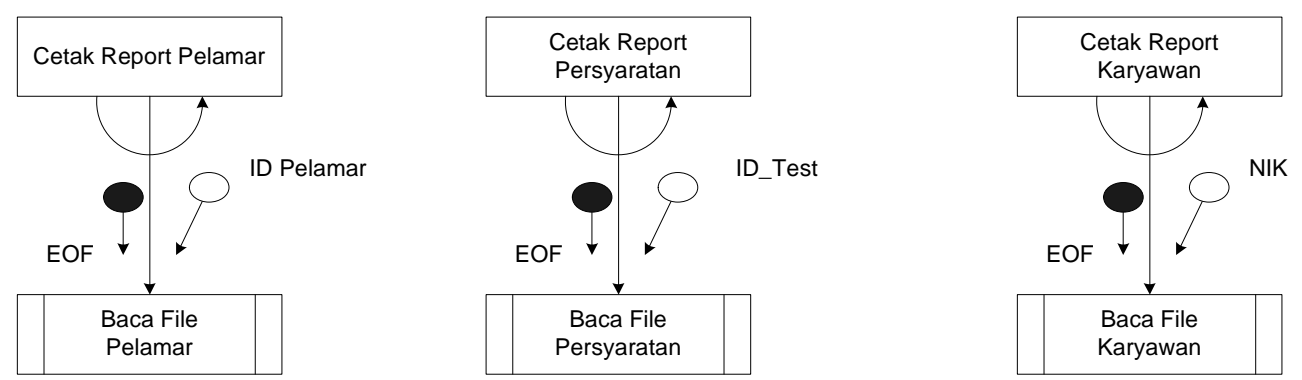

Gambar 4.20 Bagan Terstruktur Cetak Report Pelamar, Persyaratan dan Karyawan

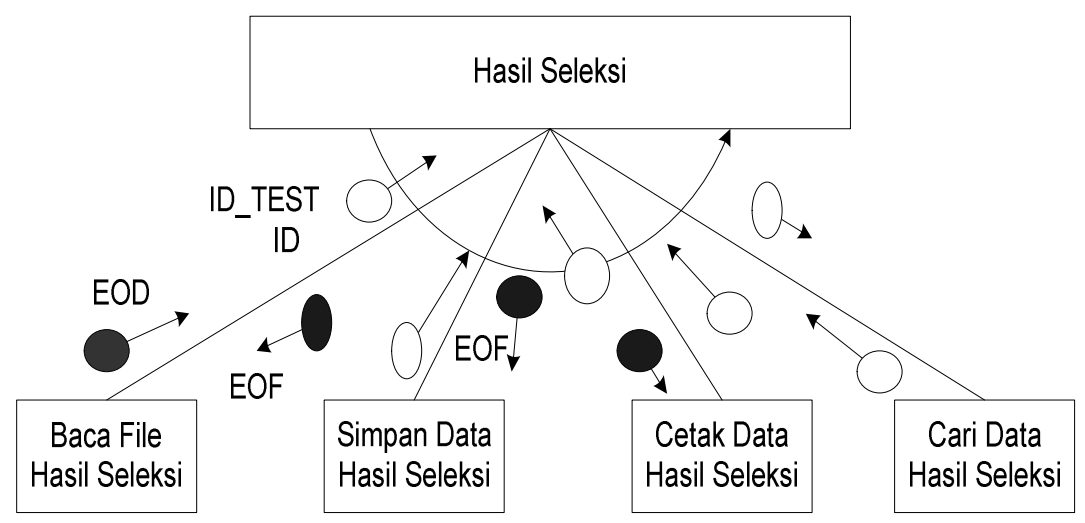

Gambar 4.21 Bagan Terstruktur Hasil Seleksi

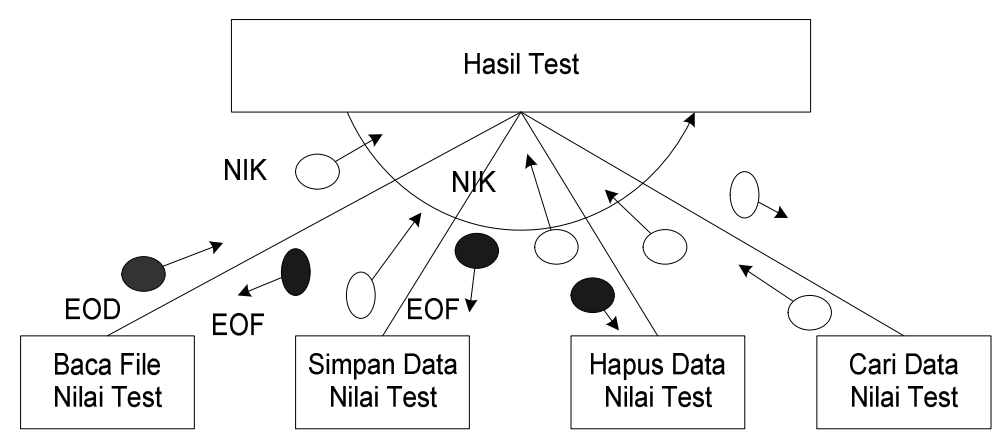

Gambar 4.22 Bagan Terstruktur Hasil Test 


\section{Pseudocode (Pengkodean)}

Pseudocode (Pengkodean) untuk data hasil seleksi, yaitu :

Baca data pelamar, data syarat

Tulis judul tabel

While data belum habis

Hitung data yang dibaca

Baca ID, ID_TEST, nama lengkap, dan lainnya

Tulis ID, ID_TEST, dan nama lengkap Pelamar

If syarat terpenuhi Then

Tulis "LULUS"

Else

Tulis "TIDAK LULUS"

End If

Wend

Tulis Penutup tabel

Selesai

Pseudocode (Pengkodean) untuk data yaitu :

Baca data hasil seleksi, nilai test

Tulis judul tabel

While data belum habis

Hitung data yang dibaca

Baca ID_TEST, NO_TEST, nama lengkap, dan lainnya

Tulis ID_TEST, NO_TEST, dan nama lengkap

Pelamar

If $\mathrm{SKOR}>85$ Then

Tulis "DITERIMA"

Else

Tulis "TIDAK DITERIMA"

End If

Wend

Tulis Penutup tabel

Selesai

Pseudocode (Pengkodean) untuk data yaitu :

Baca data Karyawan

Tulis judul tabel

While data belum habis

Hitung data yang dibaca

Baca NIK, nama lengkap, dan lainnya

Tulis NIK dan nama lengkap Pelamar

If Keterangan = "DITERIMA" Then

Tulis "NIK = Nomor Induk Karyawan"

Else

Tulis "NIK = 0"

End If

Wend

Tulis Penutup tabel

Selesai

\subsection{Rancangan Input Data.}

Proses pembuatan Aplikasi Seleksi Penerimaan

Karyawan pada Visual Basic 6 pada dasarnya sama seperti pada bahasa pemrograman lainnya. Prosedur dasar untuk membuat sebuah program aplikasi adalah:

1. Jalankan Visual Basic 6.0.

2. Membuat aplikasi baru atau membuka aplikasi yang sudah ada.

3. Menjalankan program aplikasi yang sudah dibuat.

4. Memeriksa dengan debugger yang disediakan (untuk memeriksa error atau kesalahan).

5. Menyimpan program aplikasi yang sudah dianggap selesai.

6. Mengkompilasi aplikasi untuk menghasilkan file executable yang dapat langsung dijalankan.

7. Mendistribusikan program aplikasi ke para pemakai terakhir.

8. Keluar dari Visual Basic.

Rancangan input berfungsi sebagai masukkan data untuk setiap informasi yang akan disimpan, pada Aplikasi Seleksi Penerimaan Karyawan ini dibutuhkan beberapa form input.

Adapun langkah-langkah pembuatannya adalah sebagai berikut :

1. Aktifkan MS Visual Basic 6.0.

2. Pada saat loading, keluar kotak dialog New Project, pilih standar exe atau pilih sesuai keinginan.

3. Tekan open, tampil Projectl dan New Form.

4. Bila ingin menambah form baru, klik dari menu Project, lalu pilih Add Form.

5. Tampil kotak dialog Add Form, pilih sesuai keinginan, lalu tekan open.

6. Tampil form yang baru, lihat pada gambar

7. Untuk menyimpan Project dan form pertama kali, pilih menu file lalu klik Save Project As.

8. Ketik nama file pada isian file name . Pada VB 6, yang disimpan pertama kali adalah form-form terlebih dahulu kemudian project.

9. Tambahkan toolbox yang dibutuhkan sesuai keinginan.

Form-form yang ada ini sudah melewati prosedurprosedur dalam Visual Basic, terutama dalam pemeriksaan dengan debugger. (Gambar 4.23) adalah tampilan form awal sebelum melakukan penambahan-penambahan objek yang sesuai dengan kebutuhan. 


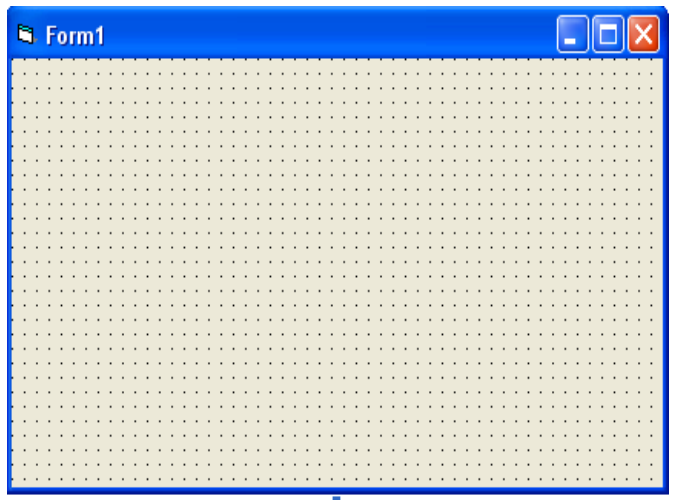

Gambar 4.23 Form awal pada Microsoft Visual Basic 6.0

\subsubsection{Display Rancangan Input Data Pelamar}

Tampilan Layar Aplikasi Seleksi Penerimaan Karyawan (SIP)

a. Form Akses Sistem (Microsoft Visual Basic 6.0)

Form ini akan muncul apabila User membuka Aplikasi Seleksi Penerimaan Karyawan ini. Dan tampilannya akan tampak seperti pada gambar 4.24 berikut :

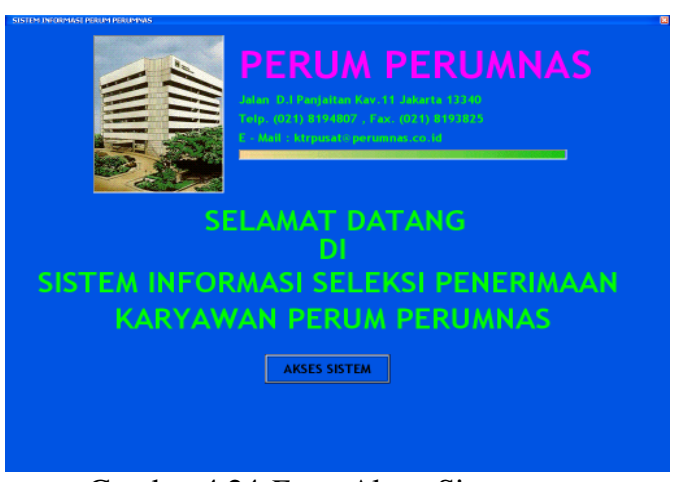

Gambar 4.24 Form Akses Sistem

b. Form Password (Microsoft Visual Basic 6.0) Form Password ini akan tampil setelah menekan tombol Akses Sistem pada tampilan awal aplikasi, seperti gambar 4.25 berikut :

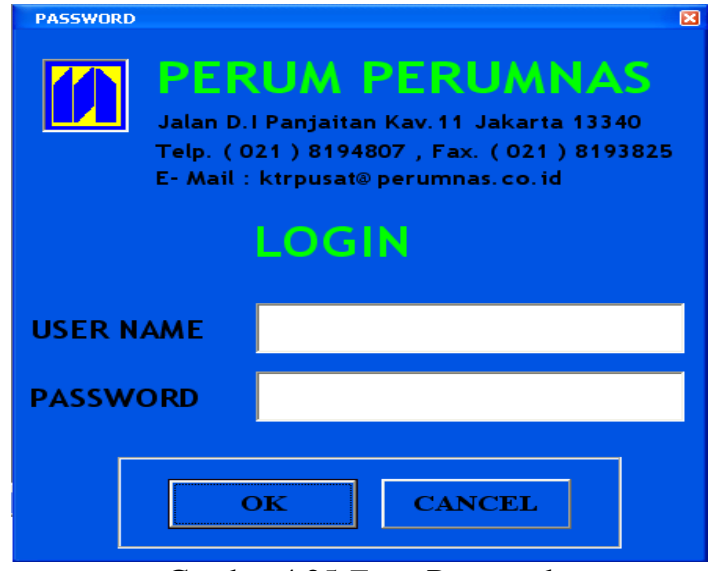

Gambar 4.25 Form Password

c. Мепи Utama (Microsoft Visual Basic 6.0)

Form ini mencangkup keseluruhan sistem kerja Aplikasi Seleksi Penerimaan Karyawan, dengan tampilan seperti berikut :

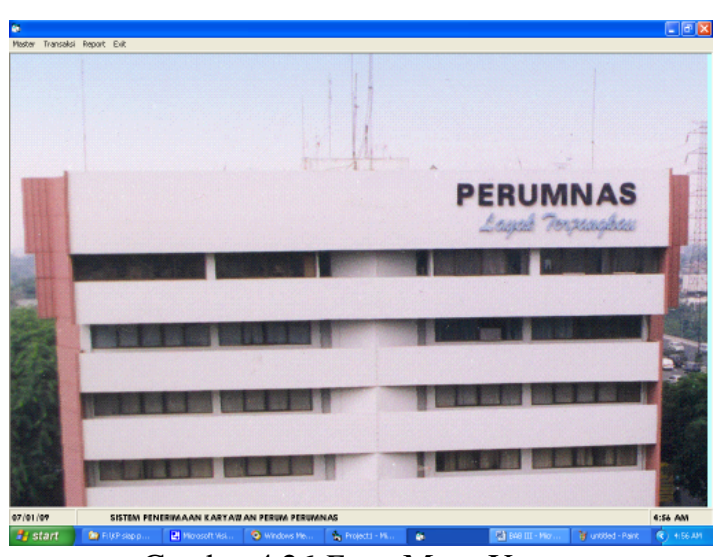

Gambar 4.26 Form Menu Utama

Keterangan Gambar 3.36 :

Untuk memilih Menu Master cukup memilih toolbar atau menekan tombol alt $+\mathrm{M}$, memilih Menu Transaksi cukup memilih toolbar atau menekan tombol alt $+\mathrm{T}$, memilih Menu Report cukup memilih toolbar atau menekan tombol alt $+\mathrm{R}$ dan memilih Меnu Exit cukup memilih toolbar atau menekan tombol alt $+\mathrm{E}$.

Menu pada form ini berisi semua perintah sistem kerja yang dapat user pilih untuk melakukan tugas tertentu sesuai kebutuhan. Untuk memilih menu bisa dengan dua cara, yaitu :

1. Dengan Mouse.

Klik dengan mouse pada menu dan sub menu.

2. Dengan Keyboard.

Tekan $A L T$ dan karakter bergaris bawah untuk memilih menu. Misalnya $A L T+\mathrm{M}$ untuk membuka menu Master. 
Pada Form ini penulis menyediakan empat menu, yaitu :

\section{1. Мепu Master}

Terdiri dari 3 Form Input, yaitu:
a. Form Input Pelamar
b. Form Input Persyaratan
c. Form Input Nilai Test

2. Мепu Transaksi

Terdiri dari 2 Form, yaitu :
a. Form Data Hasil Seleksi

b. Form Data Hasil Test

3. Report.

Terdiri dari 2 Form, yaitu : a. Output Form Berkas Pelamar

b. Output Form Berkas Persyaratan

4. Exit

Terdiri dari 1 Form, yaitu:
a. Form Exit
d. Form Input Pelamar

Form Pelamar (Microsoft Visual Basic 6.0).

Form ini dibuat untuk menginput data pelamar yang mengirimkan lamaran di PERUMNAS. Tampilan Form Input Pelamar dapat di lihat pada gambar 4.27 berikut

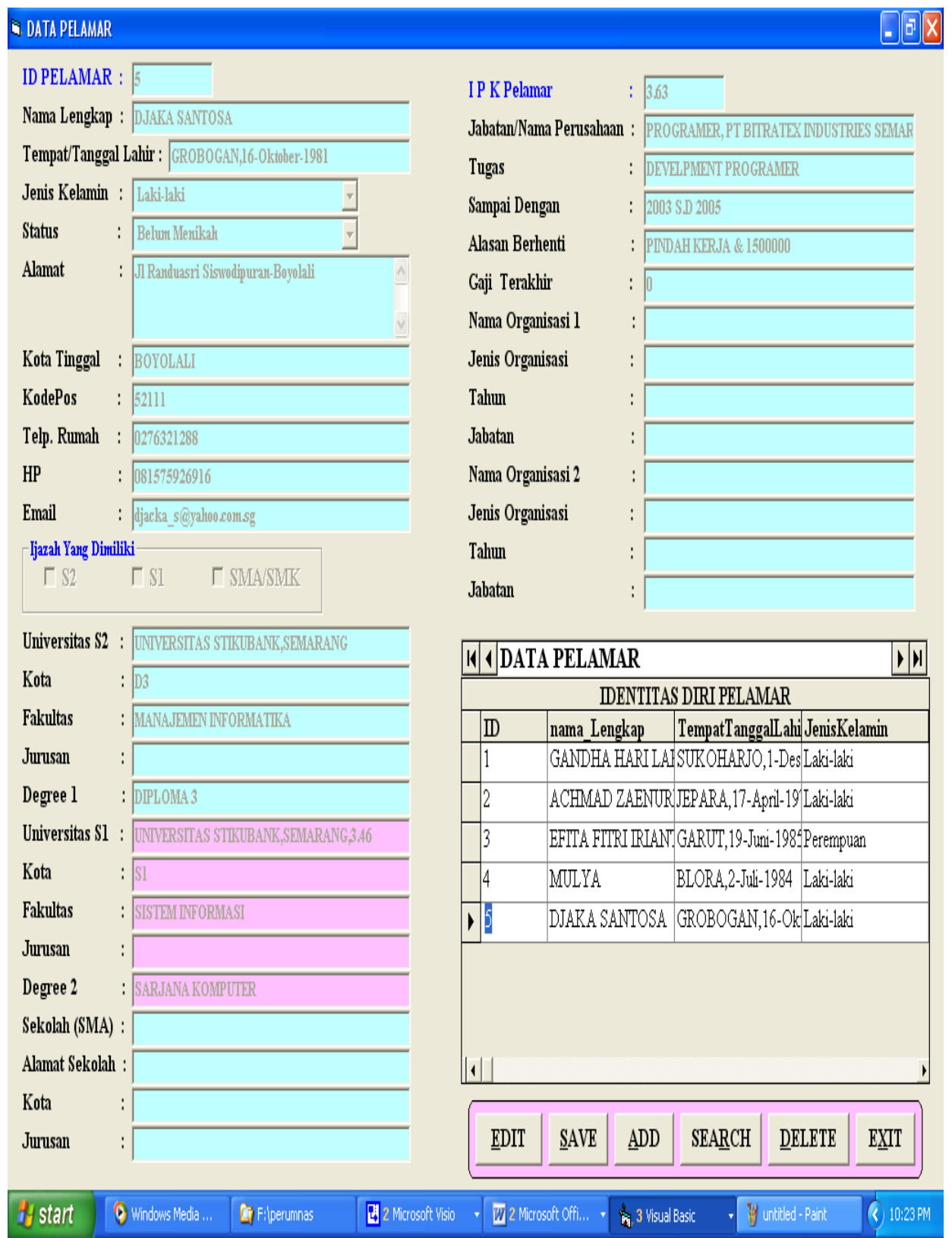

Gambar 4.27 Form Input Data Pelamar 
Keterangan Gambar :

Command Edit berfungsi untuk Mengedit atau mengubah record, Command Save berfungsi untuk Menyimpan record, Command Add berfungsi untuk Menambah record baru, setelah penambahan dan pengubahan record, Command Search berfungsi untuk Mencari record yang diinginkan, Command Delete berfungsi untuk Menghapus record dan Command Exit berfungsi untuk Keluar dari Form ini.

\subsubsection{Display Rancangan Form Input Persya- ratan}

Form Persyaratan (Microsoft Visual Basic 6.0).

Form ini dibuat untuk menginput data syarat yang harus dipenuhi oleh pelamar sebagai faktor utama penentu diterima atau tidak pelamar di PERUMNAS. Tampilan Form Input Persyaratan dapat di lihat pada gambar 4.28 berikut :

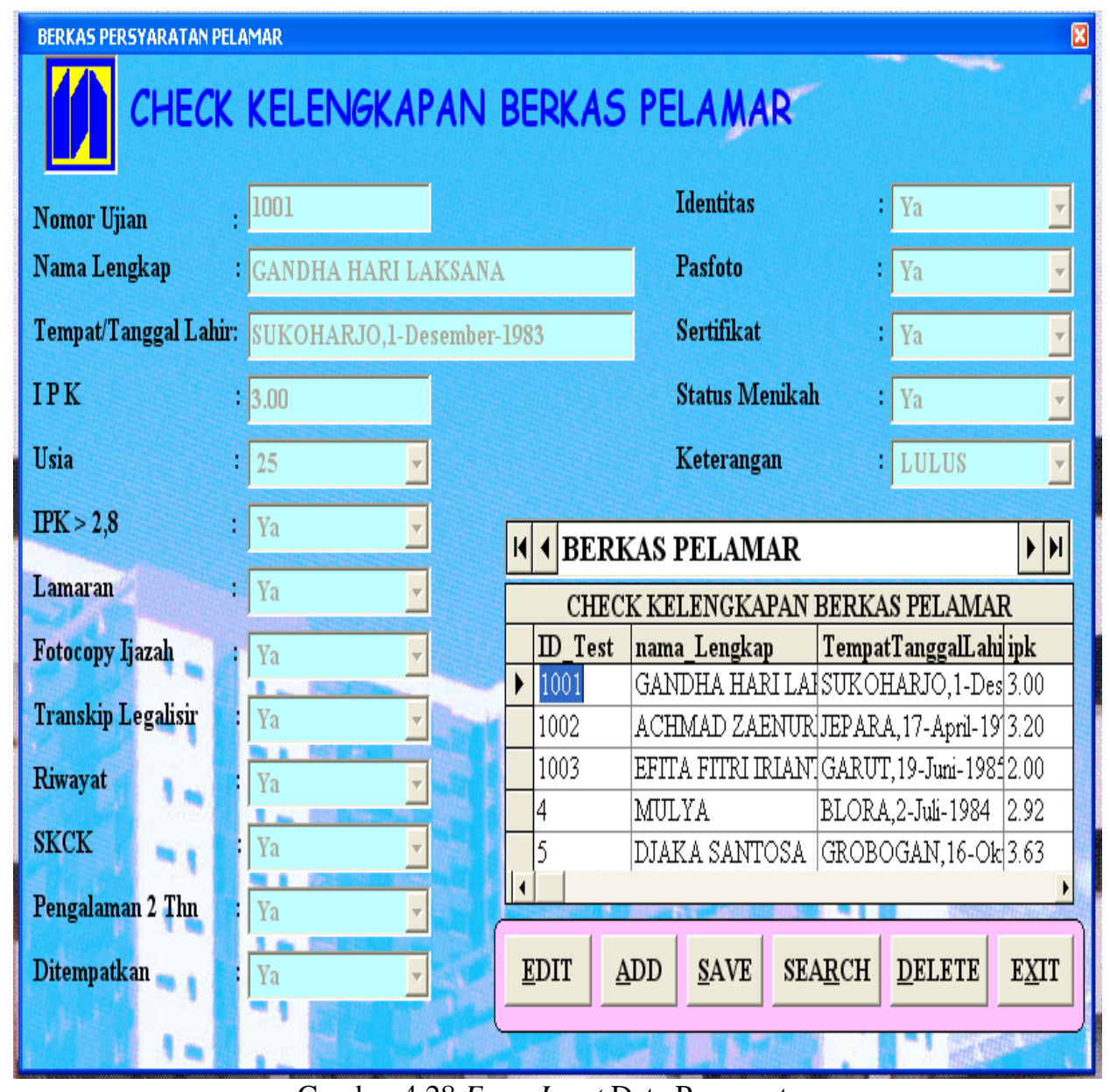

Gambar 4.28 Form Input Data Persyaratan

Keterangan Gambar :

Command Edit berfungsi untuk Mengedit atau mengubah record, Command Save berfungsi untuk Menyimpan record, Command Add berfungsi untuk Menambah record baru, setelah penambahan dan pengubahan record, Command Search berfungsi untuk Mencari record yang diinginkan, Command Delete berfungsi untuk Menghapus record dan Command Exit berfungsi untuk Keluar dari Form ini.

\subsubsection{Display Rancangan Input Nilai test}

Form Input Nilai Test (Microsoft Visual Basic 6.0).

Form ini dibuat untuk menginput data hasil (nilai test) para pelamar yang telah lulus persyaratan dan telah mengikuti test seleksi. Tampilan Form Input Nilai Test dapat di lihat pada gambar 4.29 berikut : 


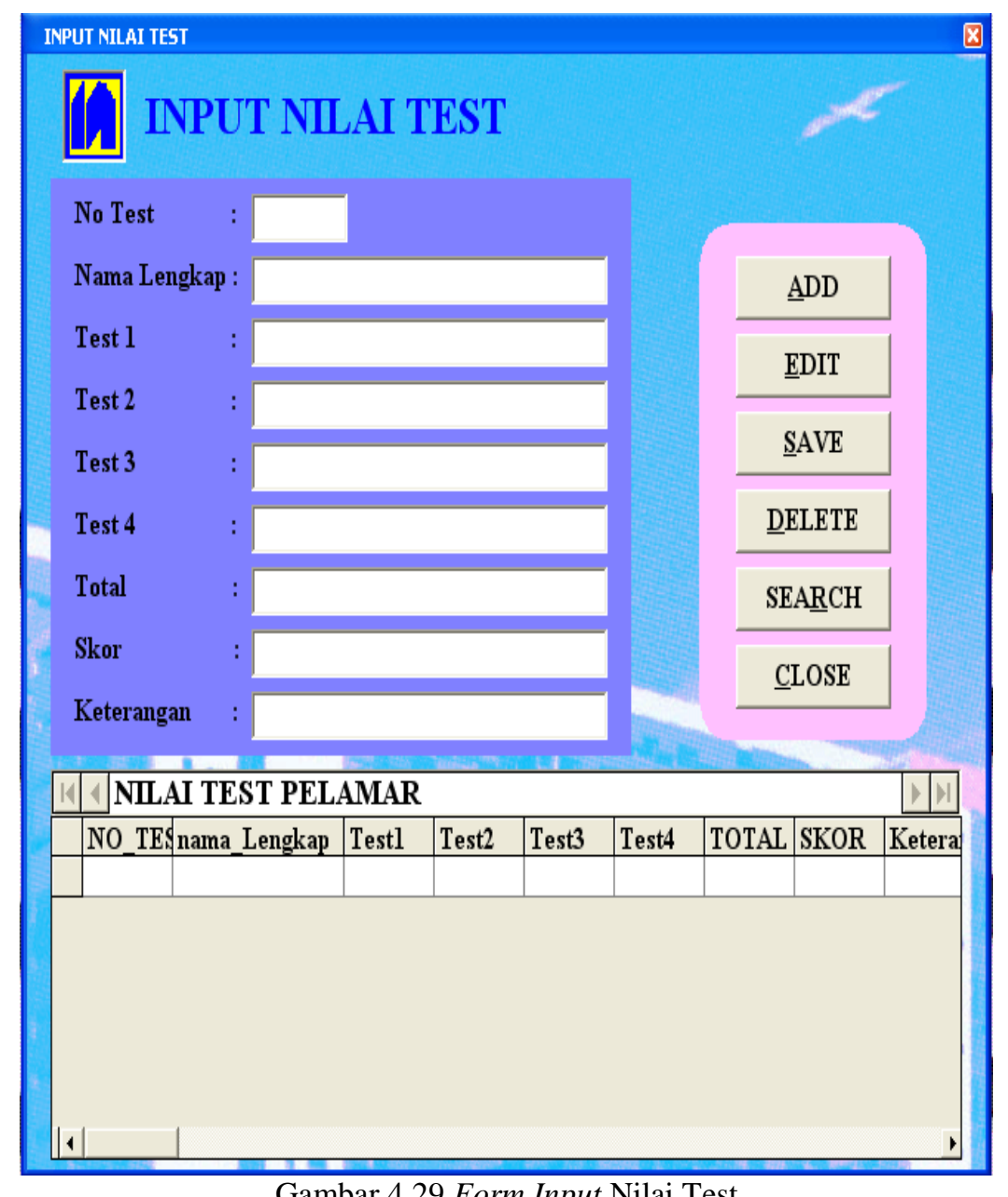

Keterangan Gambar :

Command $\underline{A} d d$ berfungsi untuk Menambah record baru, Command Edit berfungsi untuk Mengedit atau mengubah record, Command $\underline{S}$ ave berfungsi untuk Menyimpan record setelah penambahan dan pengubahan record, Command Delete berfungsi untuk Menghapus record, Command Search berfungsi untuk Mencari record yang diinginkan dan Command Exit berfungsi untuk Keluar dari Form ini.

\section{A. Pembuatan Report ( Output)}

Rancangan output ini berguna untuk melihat hasil dari input dan proses yang berupa preview pada layar dan lembar cetakan printer.

Pembuatan Form Output, terdiri dari :

1. Output Report Data Pelamar

2. Output Report Data Persyaratan

3. Output Form Data Hasil Seleksi

4. Output Form Report Nilai Test Pelamar

5. Output Report Data Karyawan
B Output Report Identitas Data Pelamar

Untuk membuat report penulis memanfaatkan fasilitas yang ada dalam Microsoft Visual Basic 6.0. sebelum masuk pembuatan report terlebih dahulu menghubungkan Microsoft Visual Basic dengan phpMyAdmin-2.10.2 adapun langkah-langkahnya sebagai berikut :

1. Klik Menu Project pada Microsoft Visual Basic 6.0

2. Klik add data environment,

3. Koneksikan dengan mengklik kanan lambang pilih Properties lalu akan tampil seperti gambar

4. Pilih Provider lalu klik Microsoft OLE DB Provider for ODBC Drivers seperti gambar 4.30 berikut : 


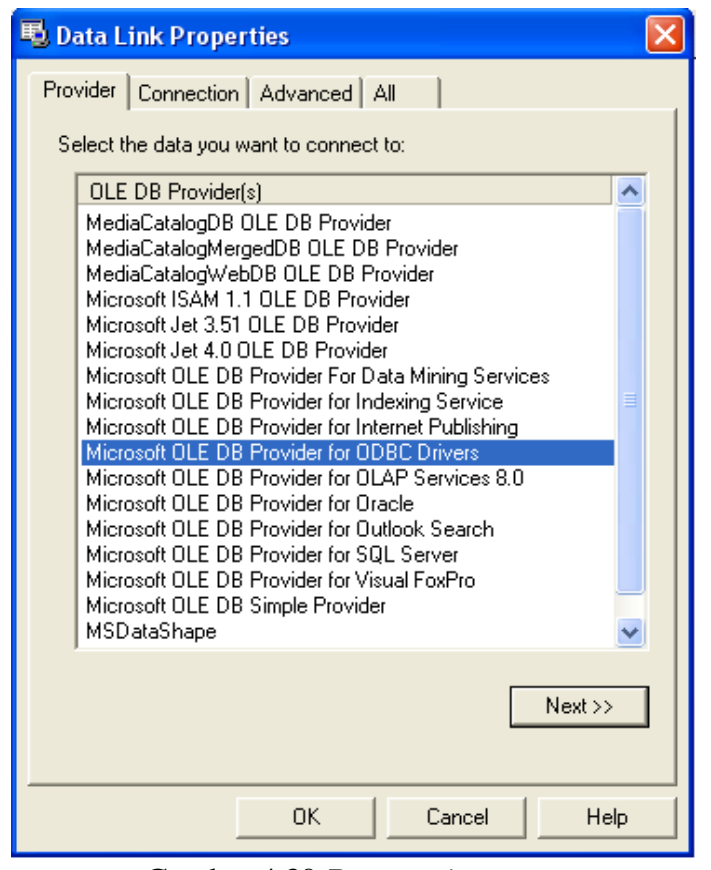

Gambar 4.30 Data environment

5. Tekan tombol Next $>>$

6. Pada Data Source tuliskan dengan database yang dimaksud yaitu : datapelamar seperti gambar 4.31 berikut :

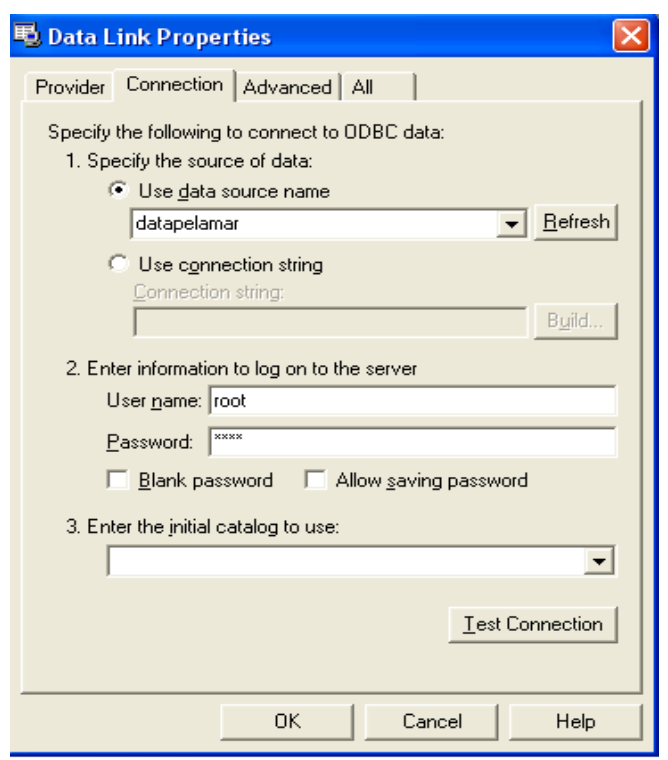

Gambar 4.31 Data source name
7. Lalu tekan tombol Test Connection, sehingga akan muncul Message Box pada gambar 4.32 berikut :

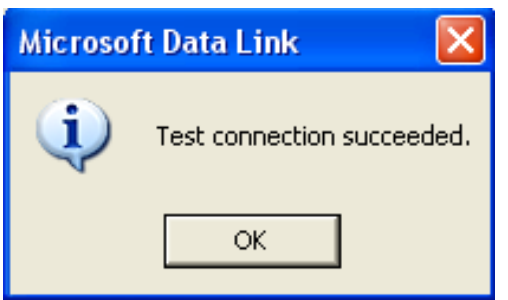

Gambar 4.32 Message Box Test Connection

8. Kemudian klik OK, sehingga menghasilkan data environment seperti Gambar 4.33

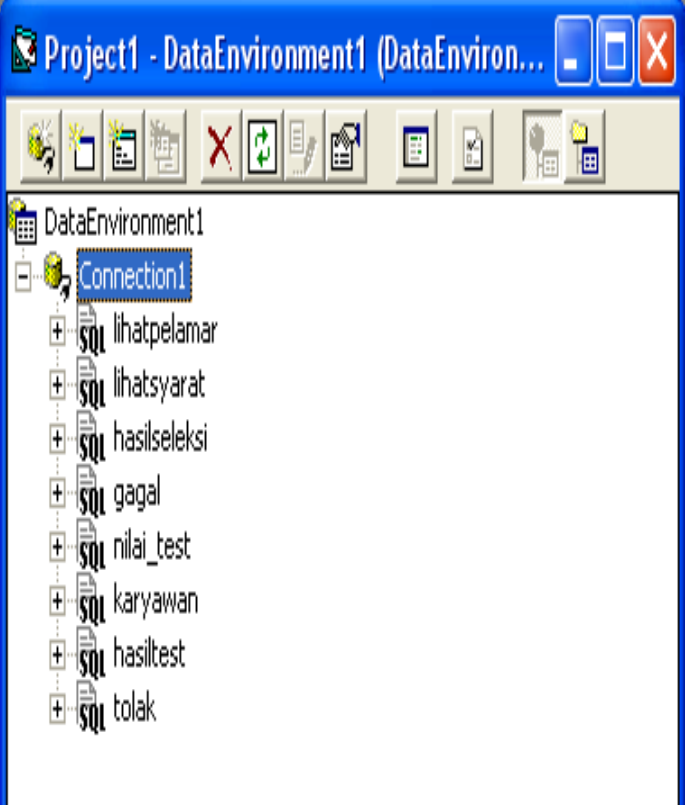

Gambar 4.33 DataEnvirontment1

9. Klik Menu Project pada Microsoft Visual Basic 6.0

10. Klik add data report

11. Data Source = DataEnvirontment1 dan Datamember $=$ lihatpelamar

12. Lalu susun pada propertiesnya sesuai dengan gambar 4.34 


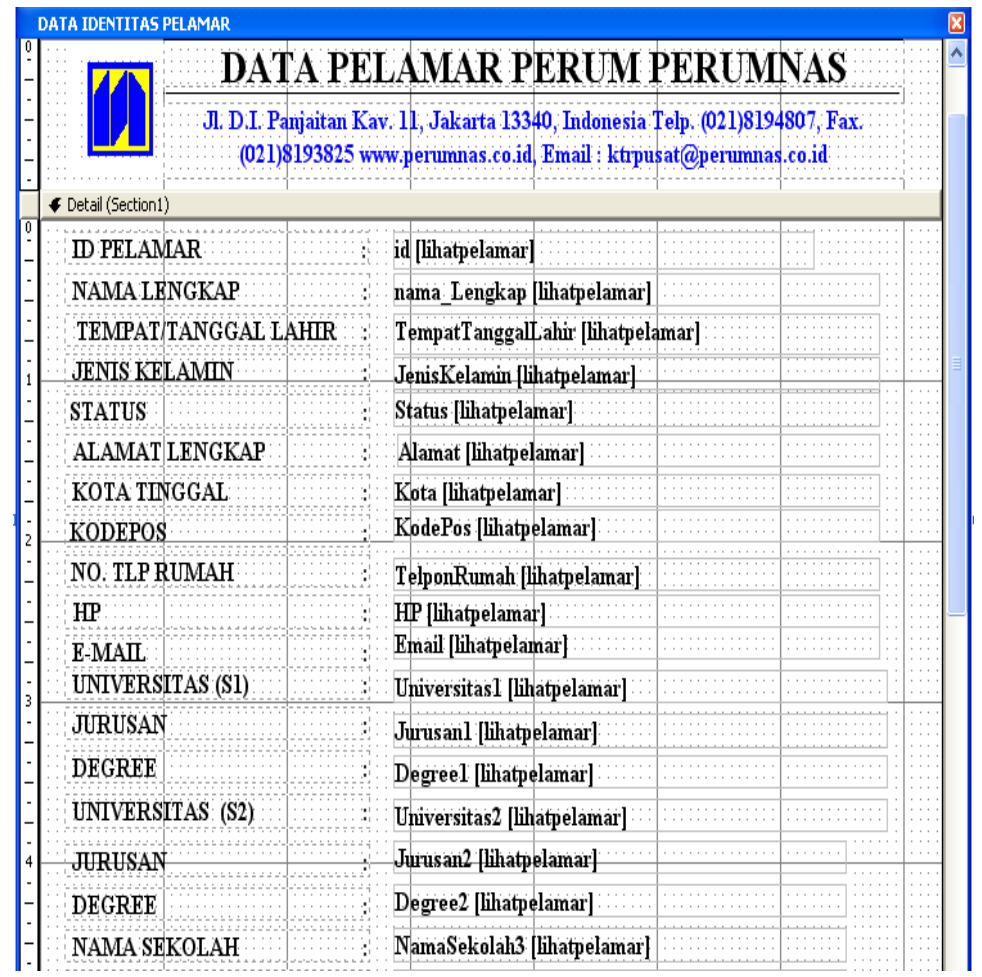

Gambar 4.34 Design Report Pelamar

13. Display Report Pelamar ( Gambar 4.35 )

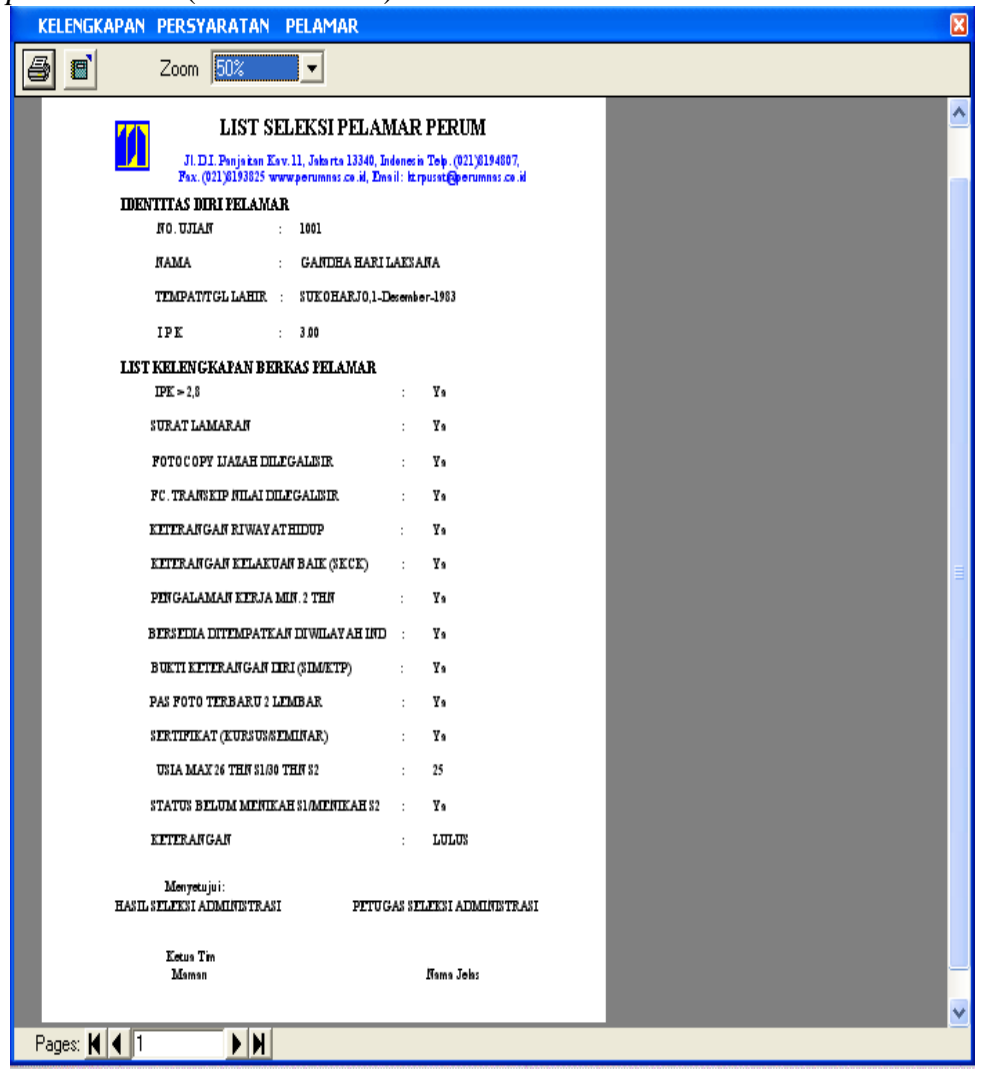

Gambar4.35 Display Report Pelamar 


\section{Output Report Data Persyaratan}

Langkah pembuatan laporan data persyaratan pelamar hampir sama dengan sebelumnya. Pada langkah 11 Data Source = DataEnvironmentl dan
Datamember $=$ lihatsyarat. Susunan Design Report Data Persyaratan (Gambar 4.36) dan Display Report Data Persyaratan (Gambar 4.37)

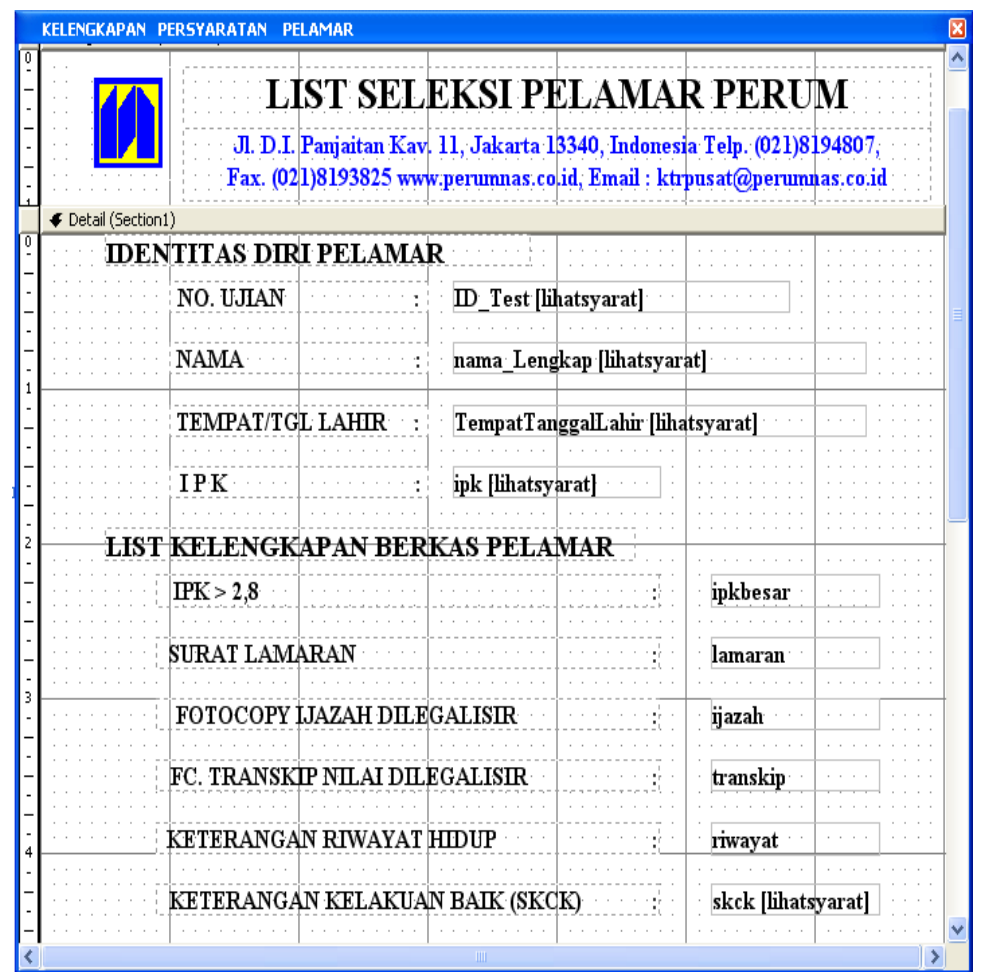

Gambar 4.36 Rancangan Laporan Persyaratan

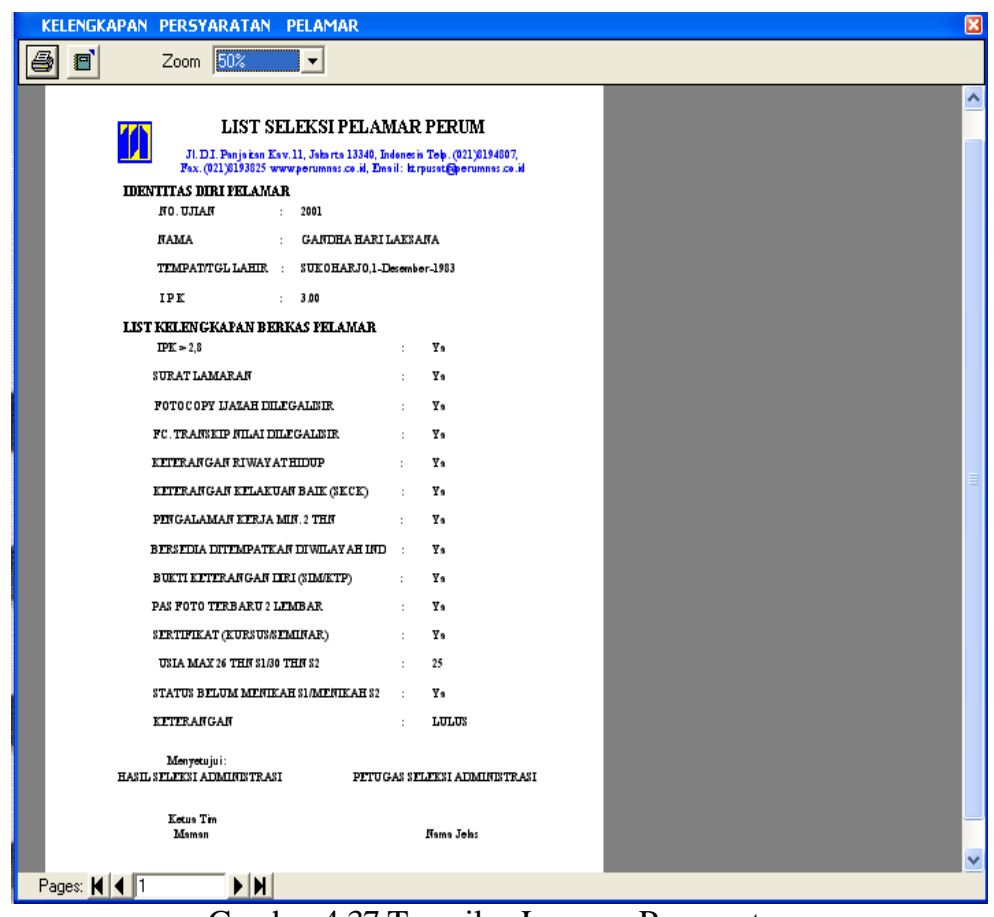

Gambar 4.37 Tampilan Laporan Persyaratan 


\section{Output Form Data Hasil Seleksi}

Langkah pembuatan laporan data hasil seleksi hampir sama dengan sebelumnya. Display Form Data Hasil Seleksi Pelamar(Gambar 4.38)

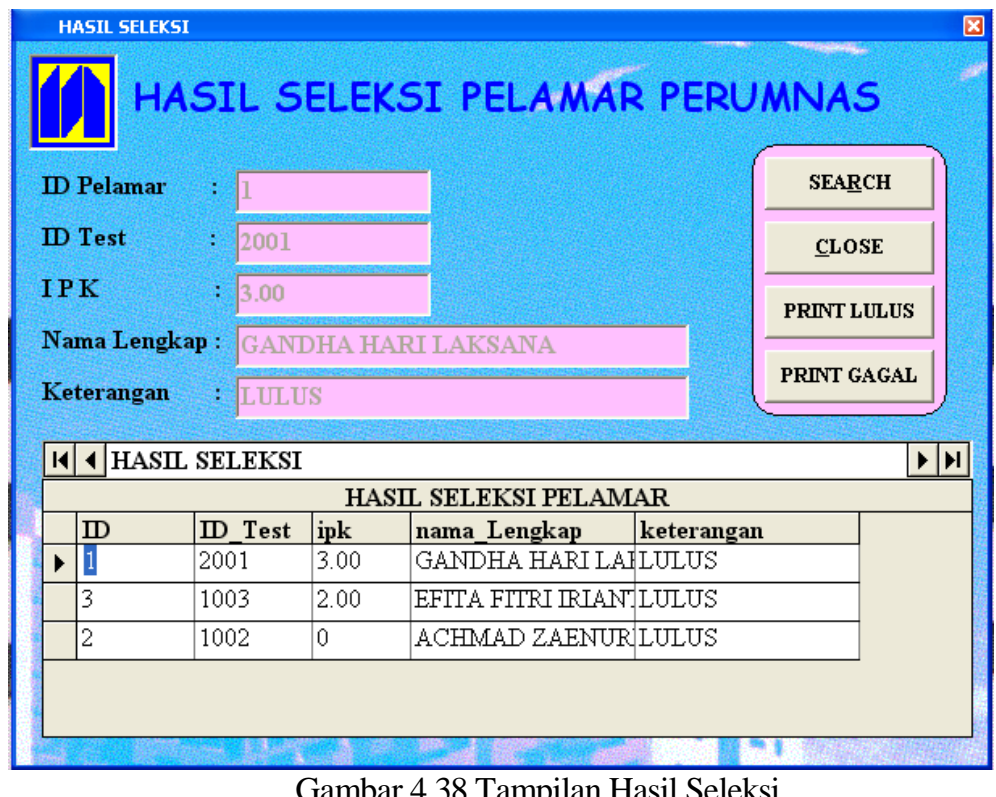

\section{E. Output Form Data Nilai Test Pelamar}

Langkah pembuatan laporan data hasil seleksi hampir sama dengan sebelumnya. Display Report Data Nilai Test Pelamar(Gambar 4.39)

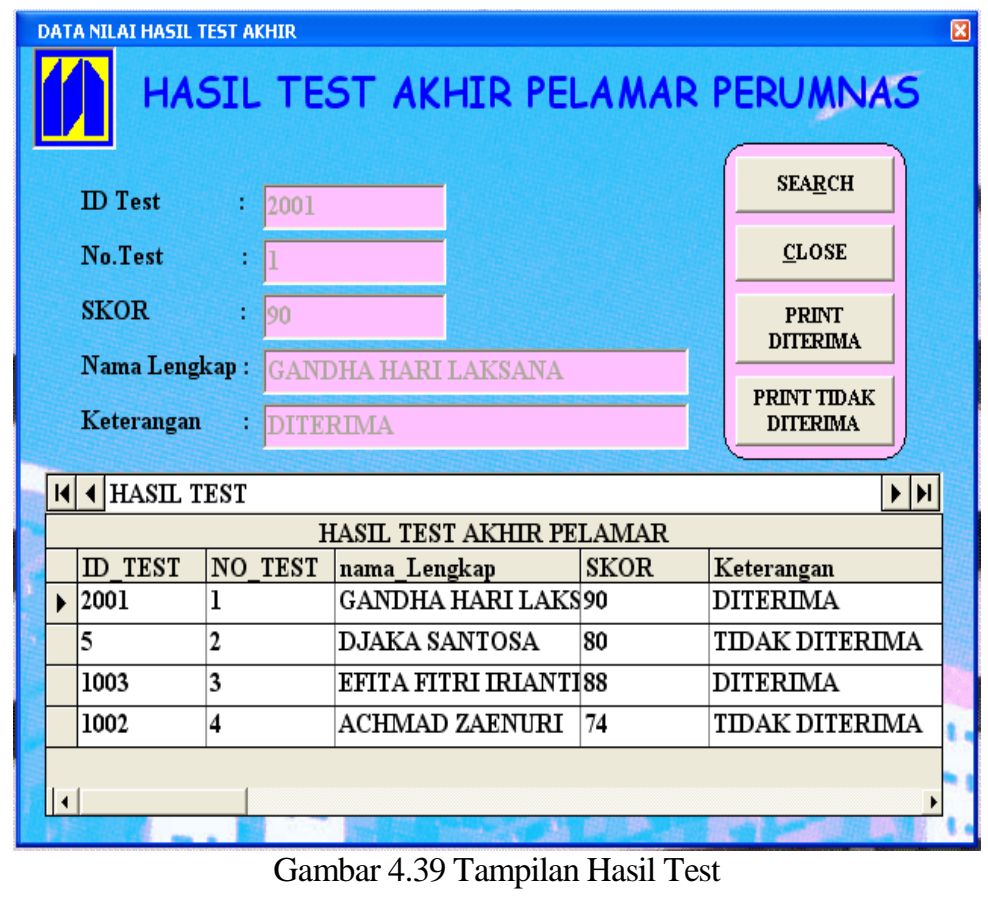




\section{F. Output Report Data Karyawan}

Langkah pembuatan laporan data sebelumnya.

Pada langkah 11 Data Source = DataEnvironment 1 dan Datamember $=$ karyawan. Susunan Design Report Data Karyawan(Gambar 4.40) karyawan hampir sama dengan

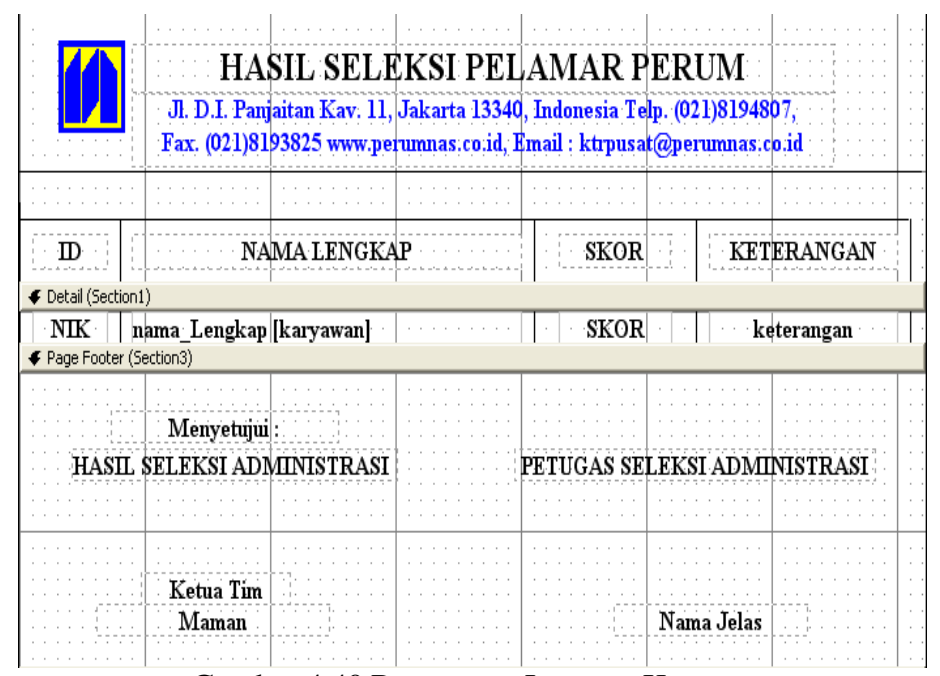

Gambar 4.40 Rancangan Laporan Karyawan

\section{G. Koneksi Database}

Konelsi database digunakan untuk menghubungkan antara database dengan aplikasi yang digunakan. Penulis menggunakan mysqlconnector-odbc-3.51.12-win32 sebagai koneksinya.

\section{H. Install (mysql-connector-odbc-3.51.12-win32)}

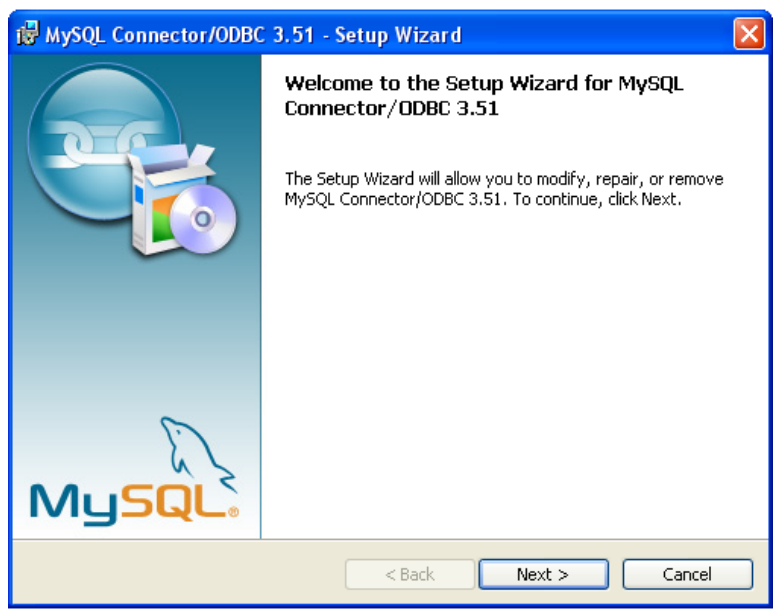

Gambar 4.41 Installing ODBC

3. Klik Next
Sebelum mengkoneksikan (menghubungkan) database dengan aplikasi Visual Basic, hal yang harus dilakukan terlebih dahulu adalah menginstall connector (penghubung). Cara menginstallnya adalah :

1. Klik dua kali pada Windows Installer Package yang telah tersedia di komputer.

2. Kemudian akan muncul tampilan berikut :

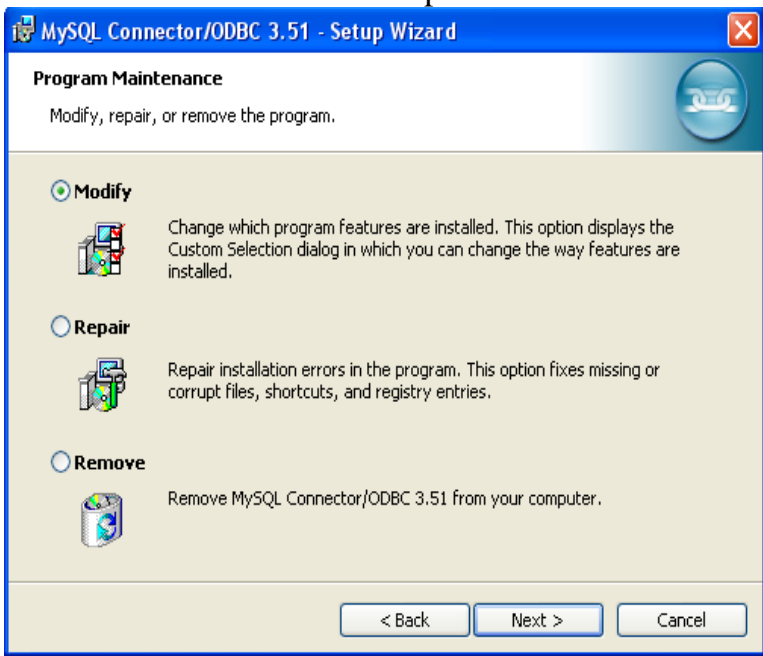

Gambar 4.42 Program Maintenance

4. Pilih Modify, kemudian klik Next 


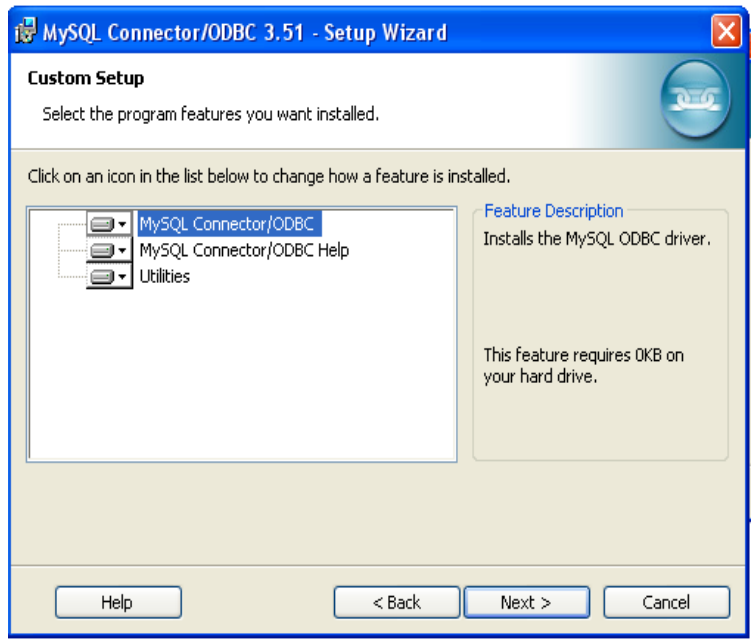

Gambar 4.43 Custom Setup

5. Klik Next, kemudian klik Install

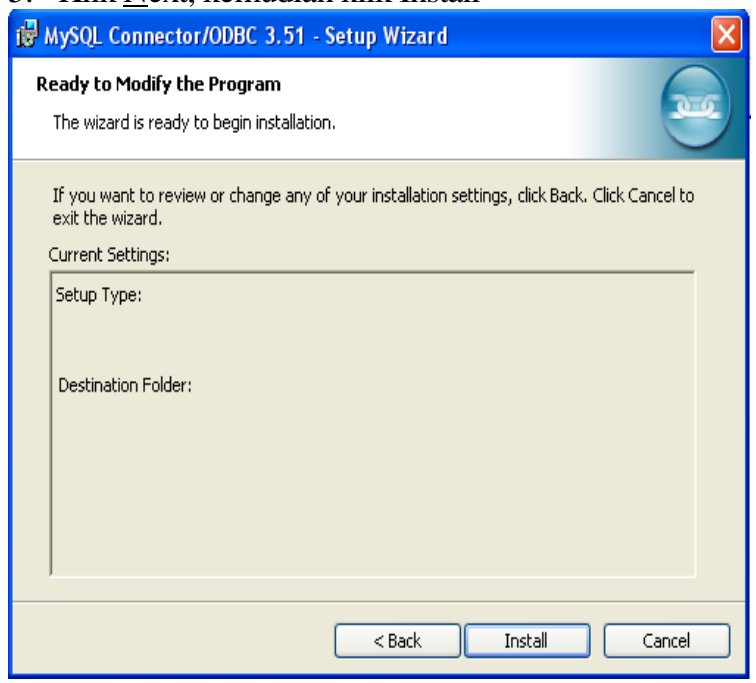

Gambar 4.44 Ready Installation

6. Maka selanjutnya klik Finish

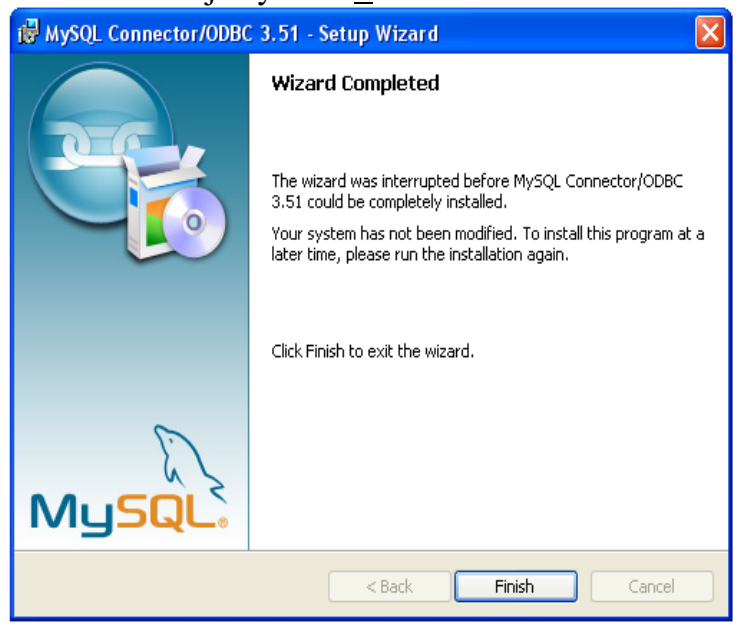

Gambar 4.45 Completed Installing

\section{Koneksi Model ODBC}

Koneksi model ODBC ini menggunakan fasilitas yang terdapat pada Control Panel. Cara membuatnya adalah sebagai berikut :

1. Aktifkan Control Panel.

2. Klik dua kali Administrative Tools

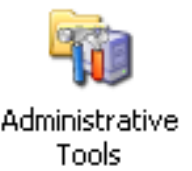

3. Klik dua kali Data Source $(O D B C)$.

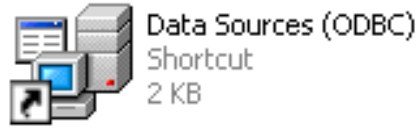

4. Klik Add.

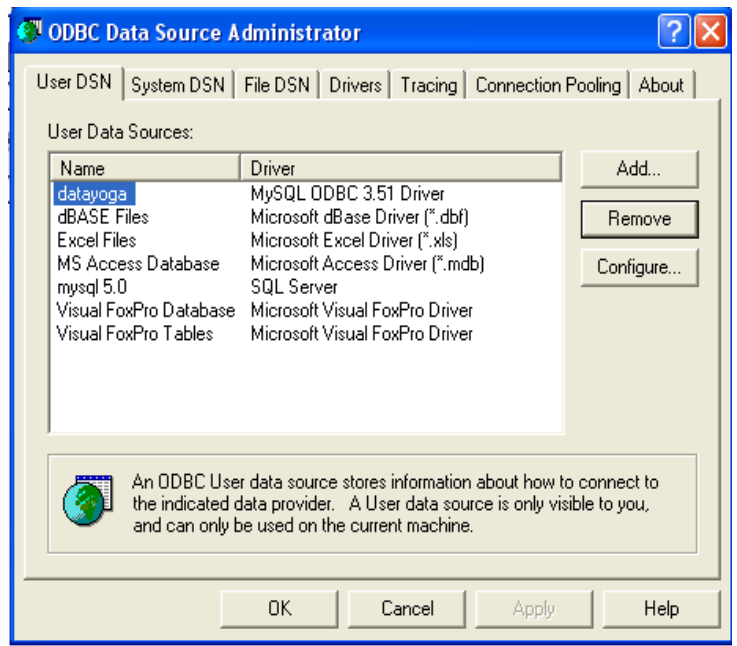

Gambar 4.46 DSN Pelamar

5. Pilih MySQL ODBC 3.51 DriverI sebagai Provider, klik Finish.

\section{Create New Data Source}

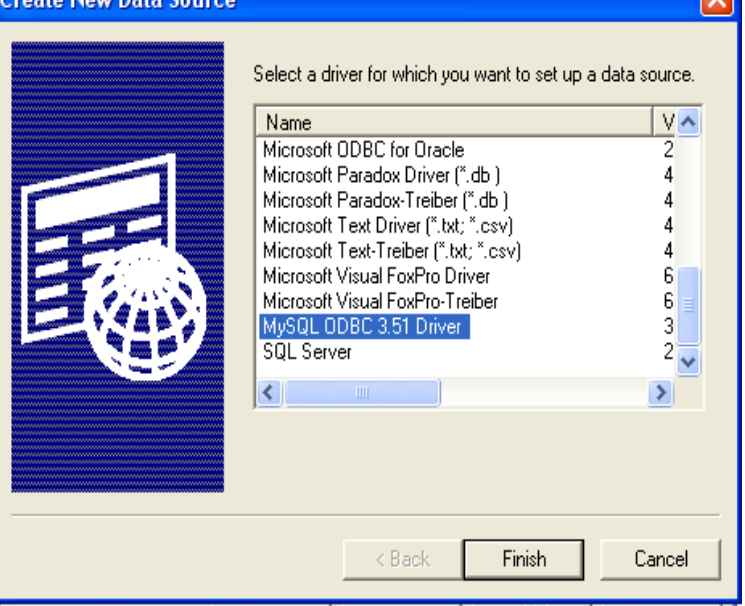

Gambar 4.47 Create New Data Source 
6. Tulis nama DSN seperti berikut, kemudian Test.

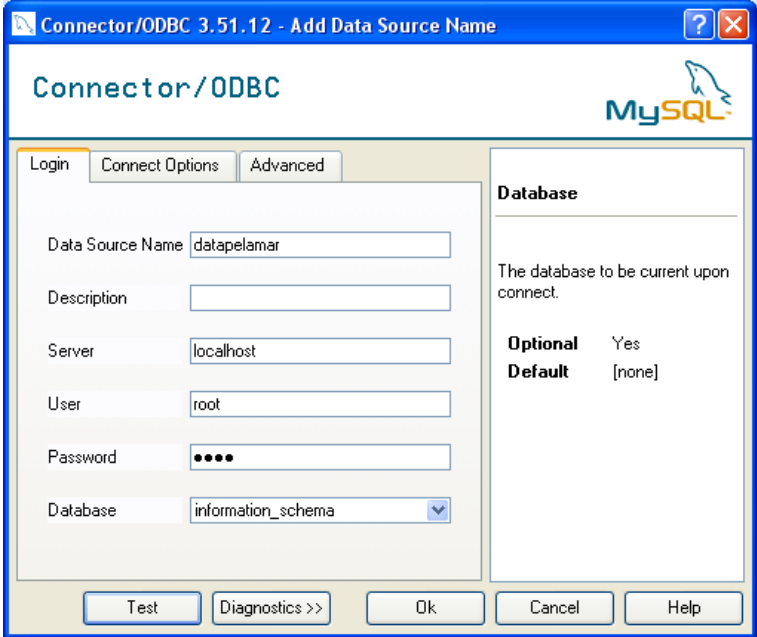

Gambar 4.48 Test Connection

7. Kemudian akan muncul pesan berikut.

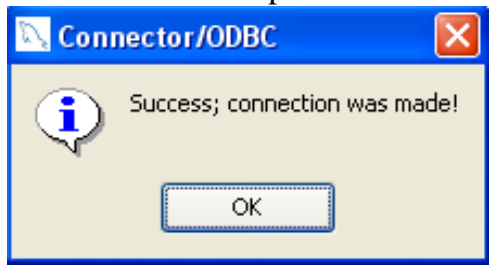

8. Apabila koneksi berhasil, maka datapelamar akan ada pada MySQL ODBC 3.51 Driver seperti berikut.

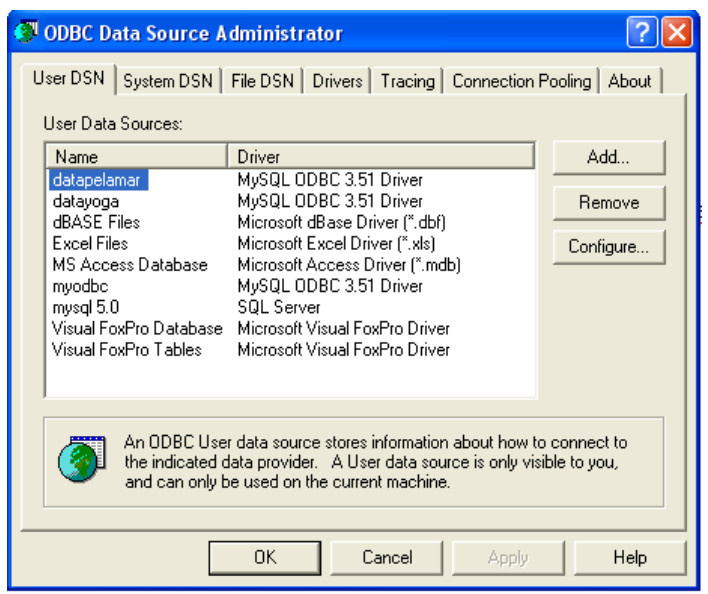

Gambar 4.49 DSN datapelamar

9. Proses selanjutnya adalah menambah System $D S N$ dan File DSN. Dengan mengikuti langkah pada nomor 4 sampai dengan 8 .

\section{J. Pembuatan EXE (Executable) Program.}

Langkah selanjutnya, setelah aplikasi seleksi penerimaan karyawan sudah selesai. Maka aplikasi yang dibuat dapat dikompilasi (Compile) untuk membentuk sebuah file Executable. File Executable adalah file yang berakhiran EXE dan dapat langsung dijalankan pada komputer tanpa harus membuka Visual Basic terlebih dahulu. File inilah yang nantinya akan didistribusikan kepada para pemakai akhir (user).

Beberapa keuntungan didalam mengkompilasi suatu aplikasi adalah:

1. Ukuran file akan menjadi jauh lebih kecil.

2. Pada saat Running time proses aplikasi akan jauh lebih cepat.

3. Lebih mudah didistribusikan kepada para pemakai akhir (end user).

4. Tidak dapat diubah-ubah atau dilihat kode sumbernya (source code) oleh user.

Langkah-langkah untuk mengkompilasi aplikasi adalah sebagai berikut:

1. Pada menu Visual Basic, penulis memilih File $>$ Make nama project

(nama project yang terdapat dalam menu diatas bergantung dari nama project Visual Basic yang telah ditentukan sebelumnya).

2. Pada kotak dialog Make Project yang muncul (dapat dilihat pada gambar ), ketikan nama yang diinginkan untuk menjadi file Executable.

Misalnya SIP.EXE

\begin{tabular}{|c|c|}
\hline Make Project & $?$ \\
\hline Save in: $\square$ perumnas & 計ヶ因当国 \\
\hline $\begin{array}{l}\text { Designer } \\
\text { Dess } \\
\text { Grorm }\end{array}$ & \\
\hline File name: $\quad$ SIF & OK \\
\hline & Cancel \\
\hline & Help \\
\hline & Options... \\
\hline
\end{tabular}

Gambar 4.50 Make Project

3. Klik tombol ok untuk mulai mengkompilasi aplikasi.

\section{K. Uji Coba Program.}

Uji coba ini telah dilaksanakan di PERUMNAS oleh penulis dengan disaksikan pimpinan (Manager) dan 3 orang user yang ditunjuk. Tujuan dari uji coba 
program ini adalah untuk mengetahui kemampuan dari aplikasi database seleksi penerimaan karyawan PERUMNAS yang telah dibuat oleh penulis. Harapan penulis dengan adanya uji coba ini adalah untuk mendapatkan jawaban dari segala kendala dan masalah yang ada serta agar dapat memberikan hasil yang maksimal, karena dengan adanya aplikasi database ini dapat menghemat waktu serta tenaga kerja yang dibutuhkan.

\section{Operating System.}

Sistem Operasi yang dipakai dalam uji coba program aplikasi ini adalah Windows XP Profesional, dimana terdapat software MS Visual Basic 6.0, phpMyAdmin-2.10.2 yang telah terinstall. Kemudian penulis memberikan saran, agar dalam penggunaan aplikasi ini juga menggunakan sistem operasi windows $X P$.

\section{Hardware}

Hardware yang dipakai penulis pada uji coba program kali ini adalah:

1. Monitor $15 " \mathrm{TVM}$

2. Processor Pentium IV

3. Hardddisk $80 \mathrm{~Gb}$ Maxtor $2 F 020 \mathrm{LO}$

4. DDRAM $256 \mathrm{Mb}$

5. VGA $64 \mathrm{Mb}$

6. Keyboard + Mouse

7. Printer Canon BJC-2100SP

\subsection{Manfaat Aplikasi Database Seleksi Peneri-} maan Karyawan PERUMNAS

Manfaat yang didapat dari Aplikasi Database

Seleksi Penerimaan Karyawan PERUMNAS ini adalah :

1. Efesiensi waktu dalam proses input data pelamar, persyaratan, dan nilai test, pencarian data pelamar, persyaratan, hasil seleksi dan karyawan, Edit dan Delete kerangkapan data.

2. Memudahkan untuk pengecekan data pelamar, persyaratan, hasil seleksi, nilai test dan karyawan.
3. Memudahkan SDM untuk membuat laporan pelamar, persyaratan, dan karyawan yang diminta oleh pimpinan (Manager).

\section{KESIMPULAN}

Dari hasil uji coba yang sudah dilakukan dan evaluasi yang dijelaskan sebelumnya, maka dapat diambil kesimpulan sebagai berikut :

1. Membantu menghindari dan mengurangi kerangkapan data.

2. Memudahkan SDM untuk menginput, mengolah data, dan mencetak laporan dari data yang masuk dan keluar sehingga menjadi lebih terkontrol.

3. Kesiapan data apabila sewaktu-waktu pimpinan (Manager) meminta laporan pengolahan Seleksi Penerimaan Karyawan secara keseluruhan.

\section{DAFTAR PUSTAKA}

1. Halvorson, Michael, Step by Step Microsoft Visual Basic 6.0 : Jakarta, PT Elek Media Komputindo Kelompok Gramedia.

2. Hartono, Jogiyanto, Pemrograman dan Sistem Informasi dan Intelegensi Buatan : Yogyakarta, ANDI YOGYAKARTA, 1999.

3. Putra, Indra, Visual Basic 6.0 : Yogyakarta, ANDI YOGYAKARTA, 2004.

4. Rusmawan, Uus, Konsep ADO untuk Tugas Akhir dan Skripsi : Jakarta, PT Elek Media Komputindo Kelompok Gramedia, 2008.

5. Supardi, Ir. Yuniar, Microsoft Visual Basic 6.0 : Jakarta, PT Elek Media Komputindo Kelompok Gramedia, 2008.

6. Yuswanto, Visual Basic 6.0 : Surabaya, PRESTASI PUSTAKA, 2002. 